\title{
TWO DECADES OF RISING INEQUALITY AND DECLINING POVERTY IN THE LAO PEOPLE'S DEMOCRATIC REPUBLIC
}

Peter Warr, Sitthiroth Rasphone, and Jayant Menon

NO. 461

November 2015
ADB ECONOMICS WORKING PAPER SERIES 
ADB Economics Working Paper Series

\section{Two Decades of Rising Inequality and Declining Poverty in the Lao People's Democratic Republic}

Peter Warr, Sitthiroth Rasphone, and Jayant Menon

No. 461 | November 2015
PeterWarr (Peter.Warr@anu.edu.au) is John Crawford Professor of Agricultural Economics, Emeritus and Director, Poverty Research Centre, Arndt-Corden Department of Economics at the Australian National University. Sitthiroth Rasphone (Sitthiroth@hotmail.com) is Research Fellow at the National Economic Research Institute. Jayant Menon (jmenon@adb.org) is Lead Economist at the Asian Development Bank.

The paper has benefited from the excellent research assistance of Lwin Lwin Aung, Ariun-Erdene Bayarjargal, and Anna Cassandra Melendez. The authors also acknowledge the kind cooperation of the Lao Statistics Bureau, Ministry of Planning and Investment, Government of the Lao People's Democratic Republic, in providing the data used in the study. Comments received from participants during the launch of the study in Vientiane and presentations to the UNDP Lao Office and the Arndt-Corden Department of Economics at the Australian National University are gratefully acknowledged. 
Asian Development Bank

6 ADB Avenue, Mandaluyong City

1550 Metro Manila, Philippines

www.adb.org

(C) 2015 by Asian Development Bank

November 2015

ISSN 2313-6537 (Print), 2313-6545 (e-ISSN)

Publication Stock No. WPS157730-2

The views expressed in this paper are those of the authors and do not necessarily reflect the views and policies of the Asian Development Bank (ADB) or its Board of Governors or the governments they represent.

ADB does not guarantee the accuracy of the data included in this publication and accepts no responsibility for any consequence of their use.

By making any designation of or reference to a particular territory or geographic area, or by using the term "country" in this document, $A D B$ does not intend to make any judgments as to the legal or other status of any territory or area.

Notes:

1. In this publication, " $\$$ ” refers to US dollars.

2. ADB recognizes "China" as the People's Republic of China, "Vietnam" as Viet Nam, and "Lao" or "Laos" as the Lao People's Democratic Republic.

The ADB Economics Working Paper Series is a forum for stimulating discussion and eliciting feedback on ongoing and recently completed research and policy studies undertaken by the Asian Development Bank (ADB) staff, consultants, or resource persons. The series deals with key economic and development problems, particularly those facing the Asia and Pacific region; as well as conceptual, analytical, or methodological issues relating to project/program economic analysis, and statistical data and measurement. The series aims to enhance the knowledge on Asia's development and policy challenges; strengthen analytical rigor and quality of ADB's country partnership strategies, and its subregional and country operations; and improve the quality and availability of statistical data and development indicators for monitoring development effectiveness.

The ADB Economics Working Paper Series is a quick-disseminating, informal publication whose titles could subsequently be revised for publication as articles in professional journals or chapters in books. The series is maintained by the Economic Research and Regional Cooperation Department. 


\section{CONTENTS}

TABLES AND FIGURES

ABSTRACT $v$

$\begin{array}{ll}\text { I. INTRODUCTION } & 1\end{array}$

II. WHY WORRY ABOUT INEQUALITY?

III. LAO PEOPLE'S DEMOCRATIC REPUBLIC: ECONOMIC GROWTH, RISING INEQUALITY, DECLINING POVERTY

A. Background on the Lao People's Democratic Republic Economy 4

B. The Lao People's Democratic Republic Data on Inequality and Poverty 5

C. Rising Inequality, Declining Poverty 8

IV. SIGNIFICANCE OF THE RISE IN INEQUALITY 16

A. Was the Increase in Inequality Statistically Significant? 16

B. How Much Did Rising Inequality Affect Poverty Reduction? 20

V. INEQUALITY WITHIN AND BETWEEN GROUPS 22

VI. INEQUALITY IN ACCESS TO PUBLIC SERVICES 26

$\begin{array}{ll}\text { VII. CONCLUSIONS } & 29\end{array}$

$\begin{array}{ll}\text { REFERENCES } & 31\end{array}$ 


\section{TABLES AND FIGURES}

\section{TABLES}

1. Inequality Measurement Data Sources: Southeast Asian Developing Countries 7

2 Mean, Median, and Decile Range of Real Household Expenditure 8

3 Expenditure Shares by Quintile 10

$4 \quad$ Average Level of Real Expenditure by Quintile Group 11

$5 \quad$ Percent Change in Real Expenditure by Quintile Group 11

$6 \quad$ Change in Real Expenditure, 1992-1993 to 2012-2013 11

$7 \quad$ Gini Coefficient by Region and Rural-Urban Location 13

$8 \quad$ Gini Coefficient by Province 14

9 Inequality by Ethnic Group 15

10 Poverty Incidence, 1992-1993 to 2012-2013 16

11 Changes in Measured Inequality, 1992-1993 to 2002-2003 17

12 Changes in Measured Inequality, 2002-2003 to 2012-2013 18

13 Changes in Measured Inequality, 1992-1993 to 2012-2013 18

14 Changes in Gini Coefficient by Province, 1992-1993 to 2012-2013 19

15 Calculation of Growth and Inequality Effects in Poverty Reduction,

16 Decomposition of Inequality into within and between Province Components 23

17 Decomposition of Inequality into within and between Rural/Urban Components 24

18 Decomposition of Changes in Inequality within and between Provinces and Rural/Urban Areas $\quad 24$

19 Decomposition of Expenditure Inequality by Ethnicity of Household Head 25

20 Access to Primary and Lower Secondary Schooling by Quintile Group 26

21 Access to Health Care Facilities and Electricity by Quintile Group 27

\section{FIGURES}

1 GDP Growth and Real GDP per Capita, 1990-2014 4

2 Mean, Median, and Decile Limits of Real Household Expenditures (1992-1993 prices), 1992-1993 to 2012-2013 9

3 Changes in Real Expenditures per Person by Centile Group, 1992-1993 to 2012-2013 12

$4 \quad$ Gini Coefficient of Inequality, 1992-1993 to 2012-2013 13

$5 \quad$ Percentage Change in Real Expenditures from 2002/2003 (LECS 3) to 2012/2013 (LECS 5) by Centile and by Major Ethnic Group $\quad 15$

6 Poverty Incidence, 1992-1993 to 2012-2013 16

7 Decomposition of Changes in Poverty, 1992-1993 to 2012-2013 21

$8 \quad$ Participation Rates by Quintile 27 


\begin{abstract}
Over the last 2 decades the distribution of private household expenditures has become more unequal in the Lao People's Democratic Republic, with the Gini coefficient rising from 0.311 to 0.364, even though absolute poverty incidence has halved. The increase in inequality was statistically significant and reduced the average rate of poverty reduction per year by about $28 \%$, meaning the actual rate compared with the counterfactual rate that would have occurred if the mean real expenditures had increased at their observed levels but inequality had not changed. When the data are decomposed into rural and urban areas of residence or by province, or by the ethnicity of the household head, the increase in inequality within groups dominates any changes between groups; inequality has increased throughout the country. In contrast, access to publicly provided services has become more equal; disparities in participation rates between richer and poorer groups have diminished.
\end{abstract}

Keywords: expenditure inequality, Gini coefficient, Lao PDR, poverty reduction

JEL Classification: D31, D39, I39 


\section{INTRODUCTION}

This paper describes changes in inequality in the Lao People's Democratic Republic (Lao PDR) over the last 2 decades and relates them to the poverty reduction that has occurred simultaneously. Since the early 1990s, five rounds of the Lao Expenditure and Consumption Surveys (LECS) have been conducted and these data are the principal information source used in this paper. ${ }^{1}$ The data measure consumption expenditures, but not incomes, at the household level. Based on this sample survey, measured inequality has increased at the national level, within both rural and urban areas and within each of the four major ethnic groups. The estimated Gini coefficient of expenditure inequality has risen from 0.311 to 0.364 at the national level and the increase in this sample-based estimate of populationwide inequality is statistically significant. At the same time, the estimated incidence of absolute poverty has halved, from $46 \%$ of the population to $23 \%$. Put together, these facts mean that the poor of the Lao PDR have become better off in real terms, but that the rich have benefited more, in both proportionate and absolute terms. A measure of the importance of this increase in inequality is that if the real expenditures of all household groups had, hypothetically, increased at the same rate, meaning that inequality had remained unchanged at its 1992-1993 level, absolute poverty incidence would have declined from $46 \%$ to $17 \%$. That is, increased inequality reduced the amount of poverty reduction that occurred over the last 2 decades by around $6 \%$ of the population, compared with the hypothetical reduction that would have occurred if inequality had not risen.

Section II reviews the reasons for concern about inequality in a poor country like the Lao PDR, drawing upon the somewhat ambivalent international economic literature on this subject. Section III summarizes the data on economic growth, inequality, and poverty incidence in the Lao PDR over the 2 decades 1992-1993 to 2012-2013, showing the coexistence of a seemingly large rise in measured inequality and a decline in absolute poverty incidence. Section IV asks whether the sample-based increase in the estimated level of inequality is a statistically significant indicator of a rise in inequality for the population as a whole and concludes that it is. This section also assesses the importance of the rise in expenditure inequality in terms of its impact on the decline in poverty incidence that occurred over the same period. Section $V$ asks whether the populationwide increase in inequality can be attributed to between-group or within-group changes, where the groups considered are provinces, rural/urban areas of residence and the ethnicity of the household head. It is shown that within-group changes dominate in all three cases. Section VI looks at the distribution across expenditure groups of access to publicly provided services, concentrating on educational and health services and access to the electricity grid. It is shown that whereas the distribution of private expenditures has become more unequal over the 2 decades covered by our data, access to publicly provided services has moved in the opposite direction, becoming more equal. Section VII concludes.

\section{WHY WORRY ABOUT INEQUALITY?}

According to a recent study by Bourguinon, economic inequality increased at a global level, from the early 1800 s to about 1980 . But since 1990 , global inequality has declined, coinciding with a fall in inequality between countries and an increase within countries (Bourguinon 2015). The rise in inequality within countries is politically sensitive and understanding global inequality requires an understanding of it. Most, but not all of the economic literature on inequality within countries has focused on rich

\footnotetext{
The survey has been conducted, analyzed, and reported upon at 5 yearly intervals from 1992-1993 to 2012-2013. The survey is conducted by the government's Lao Statistics Bureau, Ministry of Planning and Investment, with the technical assistance of Statistics Sweden and the World Bank.
} 
countries. The evidence on inequality within poor countries is mixed, but increasing inequality over the last 2 decades is a frequent observation (Zhuang 2010).

As is well-known, between the 1980s and 2000s, the People's Republic of China shifted from a low-inequality to a high-inequality country and inequality has continued to rise over the last 10 years, now ranking among the most unequal $25 \%$ of countries worldwide (Sicular 2013). A similar, though less dramatic trend has also been observed in India. Inequality has grown during the years of India's economic reforms, though poverty incidence has fallen (Chaudhuri and Ravallion 2006, Jha and Sharma 2014). In both India and the People's Republic of China higher rural-urban inequality has contributed significantly to overall inequality. Rising inequality has also been observed in several Southeast Asian countries (OECD 2013). A reversal of the trend of rising inequality has been observed in Latin America since the beginning of 2000s (Cornia 2014). Even though the level of inequality is still high compared to most other regions, a substantial decline in measured inequality has been attributed to progressive government transfers and a fall in the wage premium to skilled labor (Lustig, LopezCalva, and Ortiz-Juarez 2013). Several African countries have successfully transformed strong economic growth into poverty reduction, but the level of inequality remains high and changes in inequality have varied greatly (Liebbrandt, Finn, and Woolard 2015; Fosu 2015; Pinkovskiy and Sala-iMartin 2014).

Should poor countries (like the Lao PDR) necessarily be concerned about inequality? Surely, in low-income countries, the priority must be the reduction of absolute poverty. Taking this proposition as given, there is ample reason to think that inequality, as well as the rate of growth, can be important for poverty reduction. First, not only does an increase in inequality raise the level of poverty incidence, given the level of national income, but there is evidence (Ravallion 2007) that a high initial level of inequality reduces the amount by which poverty incidence declines for a given rate of growth.

The important complication is that the rate of growth is not necessarily exogenous. It may be influenced by the same factors that impinge on the level of inequality and changes in it. Dollar and Kraay (2002) famously showed that there is no correlation between changes in inequality and the rate of growth. That is, "on average," growth is distribution-neutral, implying that economic growth must be poverty reducing. But around this "average" story, the experiences of individual countries vary widely. The economic literature is ambivalent on the relationship between inequality and growth. On the one hand, a long-standing theoretical contention is that because richer groups save a higher proportion of their incomes, inequality promotes growth by raising aggregate savings and thus facilitating higher levels of growth-promoting investment. The empirical basis for this argument is that richer groups have higher average and marginal propensities to save. In the early stages of development, the rate of return to physical capital is high, and thus inequality promotes growth by raising the aggregate propensity to save (Kaldor 1957). The existence of investment indivisibilities in combination with poorly functioning capital markets may accentuate this effect because only the rich can afford the large outlays needed for productive capital formation (Aghion, Caroli, and García-Peñalosa 1999). ${ }^{2}$

A problem with these arguments is that "growth" is not a uniform process. Its sectoral composition may also be important. For example, the same aggregate rate of gross domestic product (GDP) growth can result from a wide range of combinations of different growth rates of agriculture, industry, and services, which may have widely different implications for the poor and for measured inequality. The question of whether "growth" raises or lowers inequality is surely crude at best.

2 Galor and Moav (2004) argue that in later stages of development, high initial inequality prevents human capital accumulation due to liquidity constraints, and becomes associated with lower growth. 
Whether higher levels of inequality produce a form of growth that benefits the poor more than the supposedly lower rates resulting from less inequality (and hence less savings) is a question that this literature does not address.

Much recent literature implies a negative relationship between inequality and growth, or more correctly, that high levels of inequality may coexist with retarded growth. But this does not necessarily mean that the two are causally related. For example, if credit market imperfections mean that the poor lack access to credit that can finance investment in physical and human capital, this will produce both higher levels of inequality than would otherwise exist and lower levels of growth. The lower growth would then not be caused by the inequality itself, but both would be the consequence of a third factor -in this case, the credit market failures. High regulatory setup costs for small business would amplify this outcome by restricting low-income people to activities in the informal sector (Aghion and Bolton 1997, Banerjee and Newman 1993, Galor and Zeira 1993). Low institutional quality can produce similar outcomes. Because of the economic and political dominance of small groups, lobbying activities may present a waste of resources derived from rent-seeking and corruption, both accentuating inequality and lowering growth (Chong and Gradstein 2007, Keefer and Knack 2002, Sonin 2003).

It is important that in this, largely theoretical literature, inequality and slow growth are both attributed to other, underlying structural problems. High levels of inequality coexist with slow growth, but the inequality does not in itself cause the slow growth. Correcting the underlying problem would both reduce inequality and improve growth. But redistributive solutions to the high inequality would not redress that underlying problem and would not necessarily raise the rate of growth. That is, rising inequality and slower growth could both be symptoms of the existence of inequality-producing and growth-retarding market failures and/or policy failures.

The extent to which inequality is bad for poor countries presumably depends on whether it is transitory or persistent. If it persists, in that inequality begets more inequality, it could increase social tensions and disruptions to peace and order. This will harm growth, and thereby undermine further attempts at reducing poverty (Alesina and Perotti 1996, Benabou 1996). Rising inequality in countries where a large proportion of the population remains poor may indicate that a significant share of the labor force is either underemployed or unemployed, or at least not participating fully in the growth process. This could put at risk the sustainability of the growth process itself. If it is transitory, in the form posited by the Kuznets (1955) hypothesis, then its detrimental effects will be short-lived. Whether rising inequality is likely to be persistent or transitory depends on a number of factors, not least the underlying causes of the high or rising inequality, as well as reactions to it through policy changes.

The linkages between poverty reduction, inequality, and growth are complex and subject to continuing controversy. What is not controversial is that for social, economic, and political reasons, economic inequality needs to be monitored and understood. That is the central task of this paper. 


\section{LAO PEOPLE'S DEMOCRATIC REPUBLIC: ECONOMIC GROWTH, RISING INEQUALITY, DECLINING POVERTY}

\section{A. Background on the Lao People's Democratic Republic Economy}

Throughout the 1970s and early 1980s, the Lao PDR remained extremely poor and isolated-the outcome of decades of conflict and inward-looking policies derived from a central planning policy framework in place since the communist takeover of 1975. In 1986, the government began decentralizing control and introducing market-oriented reforms under a revised economic strategy called the New Economic Mechanism. Early reforms under the revised strategy removed price controls, unified exchange rates, expanded foreign and interprovincial trade, and encouraged private enterprise in agriculture and manufacturing. Structural reforms continued in the 1990s through a legislative program providing the foundation for market-based rules and private sector development. The centerpiece of this program was the Lao PDR Constitution of 1991, which protects private forms of ownership.

These early reforms produced impressive results. Between 1990 and 1997, just prior to the Asian Financial Crisis (AFC), GDP growth averaged 6.4\% a year. Economic growth contracted in 1998 as a result of the AFC. A concurrent attempt by the Bank of Lao to enforce a decree requiring exclusive use of the local currency (kip) resulted in massive capital flight. Expanded public infrastructure expenditures financed by monetary expansion produced a hyperinflation in 1997 and especially 1988, but the increased aggregate demand enabled the worst effects of the AFC (as experienced in Thailand, for example) to be avoided. By 1999 real economic growth had recovered and continued reforms have since allowed growth at an average of $7 \%$ a year, despite the global financial crisis of 2008. Sustained growth allowed real per capita income to triple, from \$262 in 1990 to \$794 in 2014, in constant 2005 dollar terms (Figure 1).

Figure 1: GDP Growth and Real GDP per Capita, 1990-2014

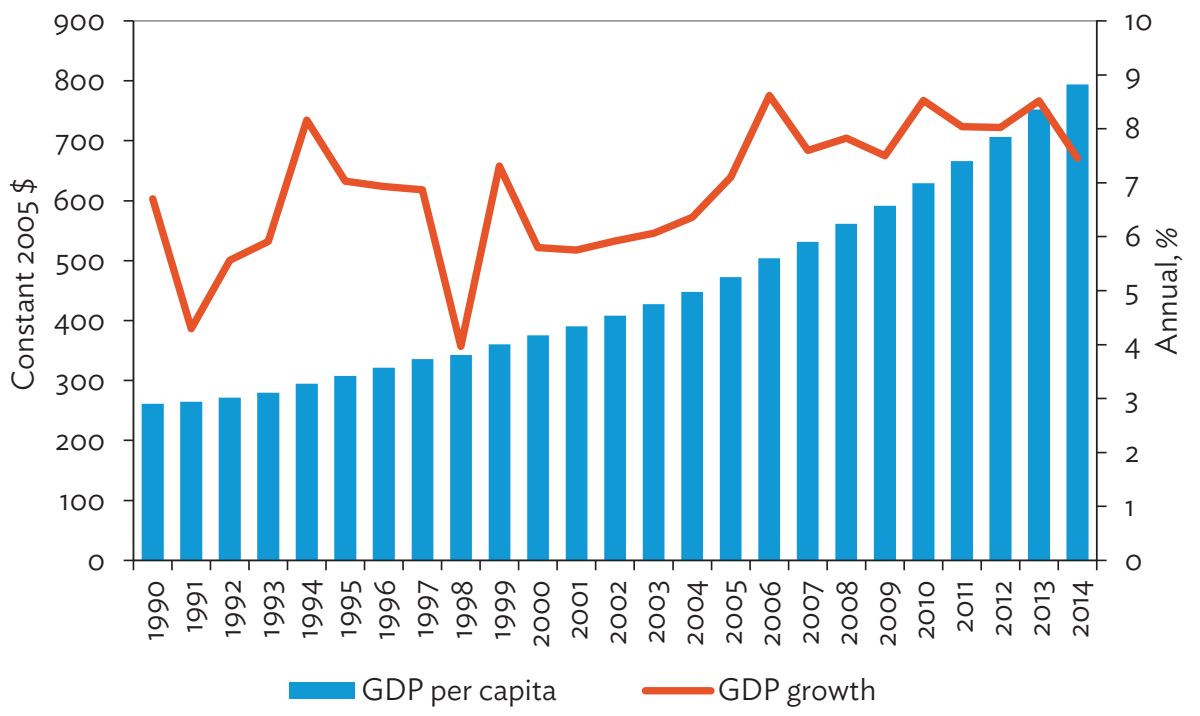

GDP = gross domestic product.

Source: Authors' calculations using data from the World Bank, World Development Indicators. http://data.worldbank.org/data-catalog/world-development-indicators (accessed 28 July 2015). 
Overall growth has been accompanied by a gradual shift away from agriculture, which had traditionally fuelled growth in the Lao PDR. The average annual growth rates of industry and services have outstripped agriculture since the 1990s and these two sectors each now account for a larger share of value-added than agriculture (Menon and Warr 2013). While agriculture accounted for about $61 \%$ of value-added in 1990 , and about $45 \%$ by 2000 , its share had fallen to about $28 \%$ by 2014 , while industry and services accounted to $31 \%$ and $41 \%$, respectively. Nevertheless, around $80 \%$ of the population (5.6 million out of the total population in 2015 of 7 million) continues to derive their income mainly from agriculture. Agriculture remains largely subsistence-based, with some emerging plantation and contract farming (UNDP 2007, World Bank 2010).

Industry's growing importance was initially fuelled by a growth in manufacturing, particularly in textiles and garments. But by 2000 nonmanufacturing industries-mining, construction, electricity, water, and gas-made up the bulk of the industry's value-added. While the share of manufacturing in GDP averaged about 14\% in the 1990s, it fell to about 8\% from 2000 onward. Resource-based output increased sharply as a share of GDP from just 5.5\% in 1999 to above $27 \%$ in 2011. Exports of minerals and electricity and investments in hydropower have driven much of this shift (ADB 2011, World Bank 2012).

\section{B. The Lao People's Democratic Republic Data on Inequality and Poverty}

Before turning to the Lao PDR evidence on inequality and poverty, the data issues involved in measuring these concepts must be reviewed. Regrettably, the methods used to measure inequality and poverty differ widely between countries and this fact limits the degree to which the resulting measures can be compared meaningfully across countries. Virtually all countries use sample surveys to collect economic data at the household level and then use these sample-based data to estimate indicators of inequality and poverty for the population as a whole. But the uniformity ends there. Some use household income as the basis for inequality and poverty estimation; others use household expenditures. Some calculate income or expenditure per household, regardless of its size, others per household member, others per "adult equivalent" at the household level. All countries include an estimate of the value of home-produced and consumed food, but seldom apply this approach to other household-produced and consumed goods and services.

Beyond this, the variables included within income or expenditure frequently differ. Some countries estimate the rental value of owner-occupied housing and add this to income or expenditures, while others do not. Countries using consumption-based methods sometimes estimate the annual value of the services derived from household-owned durable goods such as vehicles, refrigerators and so forth, others ignore them, others (including the Lao PDR) include only some such items. In an important paper, Elbers, Lanjouw, and Lanjouw (2005), point out that the precise definition of what is included and excluded is almost never the same across any two countries. Because the importance of these omitted and included items may vary with the level of household expenditures, the differences can affect measured levels of inequality, making comparisons between countries tenuous and may even affect comparisons across time for individual countries.

Table 1 illustrates this problem by comparing the data used in the estimation of inequality and poverty for the eight developing countries of Southeast Asia, including the Lao PDR. ${ }^{3}$ They vary widely. As is well-known, income-based measures (Malaysia, the Philippines, Thailand, and Viet Nam)

3 The high-income countries Brunei Darussalam and Singapore are not included in the table. 
typically show higher levels of inequality than consumption-based measures (Cambodia, Indonesia, the Lao PDR, Thailand, and Viet Nam). The Lao PDR measures consumption expenditure per capita at the household level. Expenditure items are divided into food and nonfood. Food consumption is recorded using a 30-day diary, which records all food consumed, whether purchased or homeproduced. The value of home-produced food is imputed at current market prices. Nonfood expenditures are also recorded over a 30-day period, except for (i) 12 durable goods ${ }^{4}$ and rents (cash or imputed) and (ii) a defined set of "high-value" goods. ${ }^{5}$ Category (i) items are excluded from measured consumption expenditure. However, consumption expenditures on category (ii) items are collected over a 12-month period, divided by 12 and then added to other nonfood monthly expenditures. The excluded items, such as imputed rent from owner-occupied housing (for which the Lao PDR is the only example among this group of countries), and at least some seemingly income elastic durable goods, are likely to form a larger proportion of the true expenditures of richer than poorer households. Cambodia and Myanmar also exclude many durable goods from measured expenditures, though the details vary between these three countries. ${ }^{6}$ This almost certainly means that in the Lao PDR especially, but also in Cambodia and Myanmar, the use of a consumption-based measure and the exclusion of income elastic items from measured consumption results in the underestimation of both the level of inequality and the recorded rate of increase over time, relative to most other countries.

4 The 12 excluded durable items are beds, dining and lounge suites, stoves with ovens, refrigerators, axes, sewing machines, washing machines, cars and vans, motorcycles, televisions, video cassette recorders, and computers.

5 These included high-value items are: tables and chairs, cupboards, desks and sideboards, stools and benches, carpets, lamps, rugs, mats, pictures, stoves (nonelectric), irons, electric fans, bicycles, watches, jewellery, airline tickets, expenses abroad, radio or cassettes players, cameras, other photographic and musical equipment, cellular phones and repairs of such items.

6 In Myanmar, the 2009-2010 Integrated Household Living Conditions Assessment, conducted by the Myanmar government jointly with the United Nations Development Program (UNDP) and the Swedish International Development Cooperation Agency (SIDA), calculated durable goods user cost but ultimately excluded it from nonfood consumption expenditures (IHLCA 2011). This produced estimates of the Gini coefficient of 0.19 and poverty incidence of $28 \%$. Subsequent calculations reported by the World Bank (2014) used the same survey data but included expenditures on both health and durable goods, along with other statistical changes, leading to substantially higher estimates of both measures: Gini coefficient 0.28; poverty incidence $37.5 \%$. 


\section{Table 1: Inequality Measurement Data Sources: Southeast Asian Developing Countries}

\begin{tabular}{|c|c|c|c|c|c|c|c|}
\hline Countries $^{\mathrm{a}}$ & $\begin{array}{l}\text { Data } \\
\text { Source }\end{array}$ & $\begin{array}{l}\text { Income or } \\
\text { Consumption }\end{array}$ & $\begin{array}{c}\text { Unit of } \\
\text { Observation }\end{array}$ & Imputed Rent ${ }^{\mathrm{b}}$ & $\begin{array}{l}\text { Durable } \\
\text { Goods s }^{c}\end{array}$ & $\begin{array}{l}\text { Latest } \\
\text { Gini }\end{array}$ & Latest Year \\
\hline Cambodia & Cambodia Socio-Economic Survey & Consumption per month & Per capita & Included & Partially included $^{\mathrm{d}}$ & .29 & 2012 \\
\hline Indonesia & $\begin{array}{l}\text { Survei Sosial Economi Nasional } \\
\text { (Susenas) }\end{array}$ & Consumption per month & Per capita & $\begin{array}{l}\text { Included as } \\
\text { "self-assessed rent" }\end{array}$ & Included & 0.41 & 2013 \\
\hline Lao PDR & $\begin{array}{l}\text { Lao Expenditure and Consumption } \\
\text { Survey (LECS) }\end{array}$ & Consumption per month & Per capita & Excluded & Partially included $^{e}$ & 0.37 & 2012-2013 \\
\hline Malaysia & $\begin{array}{l}\text { Household Income and Basic } \\
\text { Amenities Survey }\end{array}$ & Income per year & Per household & Included & n.a. & 0.43 & 2012 \\
\hline Myanmar' & $\begin{array}{l}\text { Integrated Household Living } \\
\text { Conditions Assessment (IHLCA) }\end{array}$ & Consumption per year & $\begin{array}{l}\text { Per adult } \\
\text { equivalent }\end{array}$ & Included & Excluded $^{\dagger}$ & 0.29 & $2009-2010$ \\
\hline Philippines & $\begin{array}{l}\text { Family Income and Expenditure } \\
\text { Survey (FIES) }\end{array}$ & Income per year & Per household & Included & n.a. & 0.46 & 2012 \\
\hline \multirow[t]{2}{*}{ Thailand } & Socio-economic Survey (SES) & Income per month & Per capita & Included & n.a. & 0.47 & 2013 \\
\hline & Socio-economic Survey (SES) & Consumption per month & Per capita & Included & Included & 0.38 & 2013 \\
\hline \multirow[t]{2}{*}{ Viet Nam } & $\begin{array}{l}\text { Viet Nam Household Living } \\
\text { Standards Survey }\end{array}$ & Income per month & Per capita & Included & n.a. & 0.40 & 2012 \\
\hline & $\begin{array}{l}\text { Viet Nam Household Living } \\
\text { Standards Survey }\end{array}$ & Consumption per month & Per capita & Included & Included & 0.36 & 2012 \\
\hline
\end{tabular}

Lao PDR = Lao People's Democratic Republic, n.a. = not available.

a Two rows appear for Thailand and Viet Nam because they produce estimates using both consumption and income data. Viet Nam uses consumption for international reporting and income for domestic reporting. Thailand reported only income-based estimates until 1986. Since then, both income and expenditure-based estimates have been produced.

b "Included" in this column means that imputed rent for owner-occupied housing is counted as an expenditure or income item. "Excluded" means that actual payments of rent are included but not imputed rent for owner-occupied housing.

c "n.a." in this column means "not applicable" because the issue arises for expenditures, not incomes.

d Included items for Cambodia are: home electronics ( 8 items), personal transport (4 items), household equipment (13 items), furniture (4 items), computers and printers ( 2 items), recreation ( 2 items), water sport (2 items), agriculture and other production ( 9 items)

e Included items for the Lao PDR are: tables and chairs, cupboards, desks and sideboards, stools and benches, carpets, lamps, rugs, mats, pictures, stoves (nonelectric), irons, electric fans, bicycles, watches, jewelry, airline tickets, expenses abroad, radio or cassettes players, cameras, other photographic and musical equipment, cellular phones and repairs of such items. Excluded items include: beds, dining and lounge suites, stoves with ovens, refrigerators, axes, sewing machines, washing machines, cars and vans, motorcycles, televisions, video cassette recorders, and computers.

f Although the IHLCA 2009-2010 calculated durable goods user cost, this was ultimately excluded from nonfood consumption expenditures.

g Myanmar's Central Statistics Office conducted Household Income and Expenditure Surveys in 1989, 1997, 2001 and 2006 (see http://www.myanmar.cm/myanmardata2009/22.htm), but the data were published only in aggregate form and estimates of inequality measures were not reported. Two Integrated Household Living Conditions Assessment surveys (IHLCA) were conducted in 2004-2005 and 2009-2010, with assistance from the UNDP, UNICEF and SIDA. This has been the primary data source for poverty and inequality estimates subsequently published by UNDP (2011)

Sources: Cambodia National Institute of Statistics 2013; Ministry of Planning, Cambodia; Soukhathammavong, Duanmany, and Sisoulath 2012; Priebe 2014; Statistics Indonesia 2014a, 2014b; Department of Statistics, Malaysia 2012, 2015; Malaysia Economic Planning Unit 2013; UNDP 2011; Integrated Household Living Conditions Survey in Myanmar (2009-2010) Technical Report; Integrated Household Living Conditions Survey in Myanmar (2009-2010) Poverty Profile; World Bank 2014; Philippine Statistical Agency 2003, 2013; National Statistical Office, Thailand; Statistical Yearbook, Thailand 2013; Kozel 2014; General Statistics Office, Viet Nam 2012; Phuong et al. 2012. 


\section{Rising Inequality, Declining Poverty}

Table 2 summarizes the mean and median levels of real consumption expenditure per person in the Lao PDR for the years 1992-1993 and 2012-2013, using the LECS data and the nationwide consumer price index. ${ }^{7}$ The data also show the P10 to P90 decile range, meaning the levels of real expenditure per person below which the poorest $10 \%$ and poorest $90 \%$ of the population are located, respectively. ${ }^{8}$ These data are shown for the total population and for rural and urban areas. The mean exceeds the median in all cases, reflecting the asymmetry of the distribution of expenditures-skewed toward higher levels of expenditure. Both mean and median real expenditures increased in all cases. The P90 to P10 decile values both increased, but the range between them expanded because the proportional increases in the P90 values were much larger, reflecting an increase in the spread of the distribution. The final column shows the coefficient of variation of real expenditures (standard deviation divided by the mean), indicating a 38\% rise in the dispersion of the distribution of the total population. This proportional change was similar for rural and urban areas. These data are summarized graphically in Figure 2, with the intermediate years 1997-1998 and 2002-2003 also shown. In the diagrams, the circular dots at the bottom and top of the vertical lines for each year indicate the P10 and P90 levels of real expenditure, respectively. Leaving aside the somewhat anomalous results for 1997-1998, the data show a progressive increase in both mean and median real expenditures, but also a widening of the distribution. ${ }^{9}$

Table 2: Mean, Median, and Decile Range of Real Household Expenditure (1992-1993 prices)

\begin{tabular}{lcccccc}
\hline & & & & \multicolumn{2}{c}{ Decile Range } & Coefficient \\
\cline { 5 - 6 } Year & Location & Mean & Median & P10 & P90 & of Variation \\
\hline \multirow{2}{*}{$1992-1993$} & Rural & 9,676 & 8,289 & 4,695 & 16,024 & 0.59 \\
& Urban & 16,014 & 13,060 & 7,474 & 28,396 & 0.65 \\
& Total & 11,170 & 9,202 & 5,029 & 19,331 & 0.68 \\
\multirow{2}{*}{$2012-2013$} & & & & & & \\
& Rural & 14,104 & 11,398 & 6,157 & 24,030 & 0.83 \\
& Urban & 22,889 & 16,911 & 8,587 & 41,493 & 0.94 \\
& & & & & & \\
& Total & 16,549 & 12,675 & 6,557 & 29,564 & 0.94 \\
\hline
\end{tabular}

Notes: Units of real household expenditure are kip per person per month, 1992-1993 prices. The coefficient of variation is the standard deviation divided by the mean. "Decile range" means, in the case of P10, the level of real expenditure below which the poorest $10 \%$ of the population is located; and in the case of P90, the level below which the poorest $90 \%$ of the distribution is located.

Source: Authors' estimations using LECS data and consumer price index data from Lao Statistics Bureau.

7 The deflator is calculated as the monthly average of the consumer price index (CPI) over the 12 months of LECS data collection for each survey period. LECS data are collected from March of one year to February of the following year. For example, LECS 1 data were collected March 1992 to February 1993. The CPI deflator for the LECS 1 survey is thus the simple average of the monthly CPI levels over these 12 months. For the LECS 2 survey, it is the average CPI from March 1997 to February 1998, and so forth.

8 By this definition, the median is equivalent to the P50 level of real expenditure.

9 The years 1997-1998 were a period of economic turbulence in the Lao PDR, as noted above. The contractionary impact of the Asian financial crisis, which began in neighboring Thailand, was followed by a hyperinflation within the Lao PDR induced by monetary expansion (Menon and Warr 2013), during which annual rates of inflation were well over $100 \%$. The large and temporary increase in measured inequality over the period ending in 1997-1998 may be partly attributable to those events. The data on real expenditures in 1997-1998 may be less reliable than those for other years because the rate of increase in the CPI may have been underestimated during the hyperinflation, resulting in overestimation of measured increases in real expenditures. 


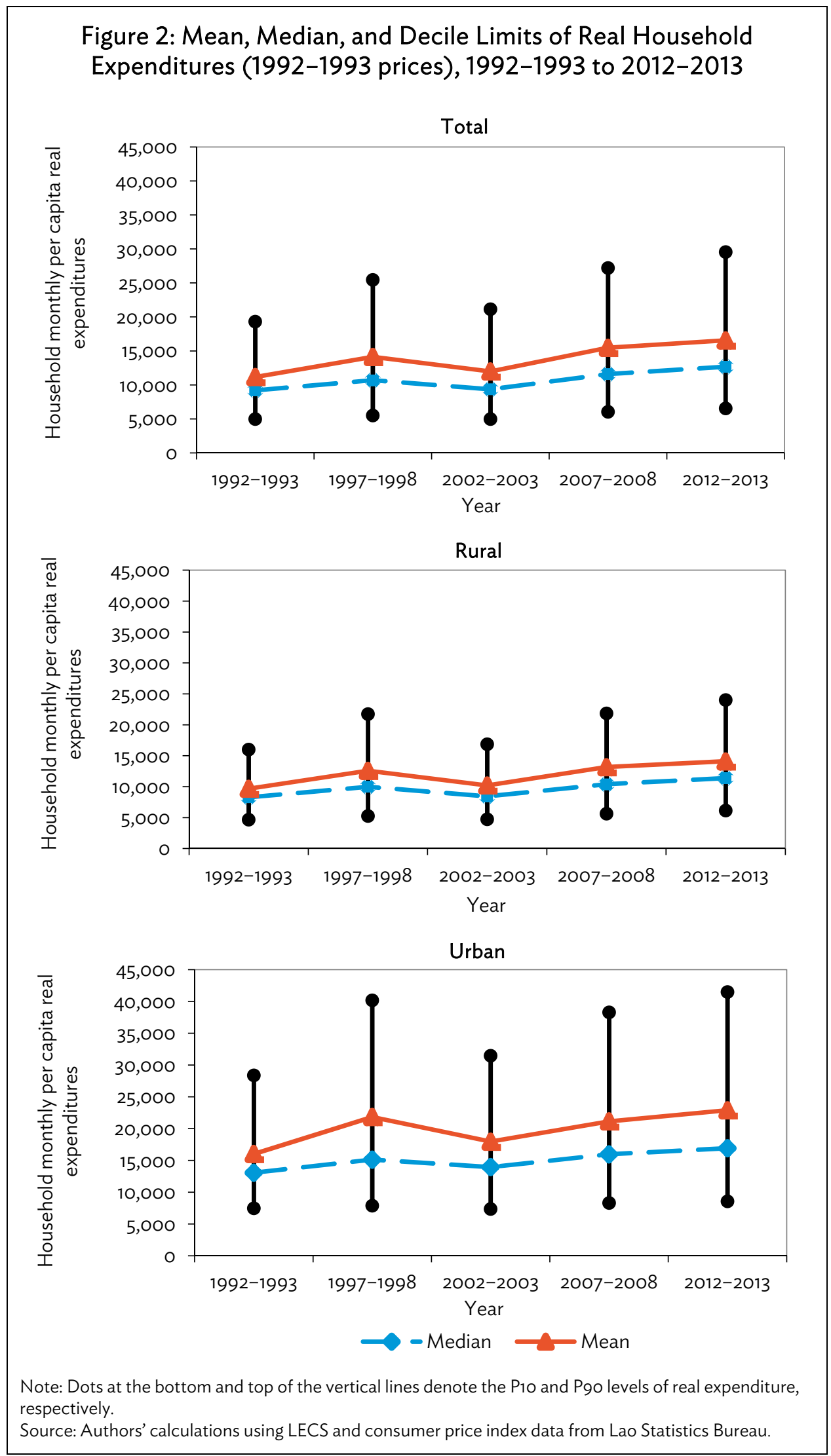


This widening of the distribution can also be seen in Table 3, which summarizes shares of total consumption expenditure per person, classified by quintile group (poorest 20\%, next poorest 20\%, and so on, up to the richest 20\%). Over the 2 decades since the early 1990 s, the poorest quintile's share of total consumption declined from $8.7 \%$ to $7.6 \%$, while the richest quintile's share rose from $40.2 \%$ to $44.8 \%$. Only the richest quintile group experienced an increase in its share of total consumption; every other quintile group's share declined.

Table 3: Expenditure Shares by Quintile

(\% of total expenditures)

\begin{tabular}{lccccc}
\hline Quintile Group & $\begin{array}{c}1992-1993 \\
\text { (LECS 1) }\end{array}$ & $\begin{array}{c}1997-1998 \\
(\text { LECS 2) }\end{array}$ & $\begin{array}{c}2002-2003 \\
\text { (LECS 3) }\end{array}$ & $\begin{array}{c}2007-2008 \\
\text { (LECS 4) }\end{array}$ & $\begin{array}{c}\text { 2012-2013 } \\
\text { (LECS 5) }\end{array}$ \\
\hline Quintile 1 (poorest) & 8.7 & 7.4 & 8.1 & 7.6 & 7.6 \\
Quintile 2 & 12.8 & 11.4 & 11.9 & 11.5 & 11.5 \\
Quintile 3 & 16.5 & 15.2 & 15.6 & 15.1 & 15.3 \\
Quintile 4 & 21.8 & 20.7 & 21.1 & 20.9 & 20.8 \\
Quintile 5 (richest) & 40.2 & 45.3 & 43.3 & 44.9 & 44.8 \\
\hline Total & 100 & 100 & 100 & 100 & 100 \\
\hline
\end{tabular}

LECS = Lao Expenditure and Consumption Survey.

Source: Authors' calculations using LECS data from Lao Statistics Bureau.

Table 4 shows that over the 20-year interval between 1992-1993 and 2012-2013, average real expenditure per person increased for every quintile group. That is, every quintile group benefited (on average) in real terms, but not at the same rates. Table 5 shows the percentage changes of real expenditures for each quintile group across each of the 5-year intervals between the LECS surveys, based on Table 4. By comparing each group with the mean, it can be assessed which group fared better or worse, in proportional terms, from any departures from distributional neutrality. Since we are most interested in long-term changes in inequality and poverty, Table 6 summarizes the proportional change of real expenditure for each quintile group over the full 20-year interval from 1992-1993 and 2012-2013. For quintile 1 (the poorest), real expenditure increased by $30.2 \%$, clearly a positive outcome. But the real expenditure of quintile 5 (the richest) increased at more than twice this rate, at $65 \%$. Indeed, the proportional increase for each successive quintile group exceeded that for the quintile group below it: the proportional increase for quintile 5 exceeds quintile 4, which exceeded quintile 3 , and so forth. Only the richest quintile experienced an increase larger than the mean.

If we focus on absolute changes in real consumption, rather than proportional changes, the disparity in the experiences of different quintile groups is amplified and the increase in measured inequality becomes more graphic, because richer groups start with a larger base. ${ }^{10}$ These calculations are summarized in the second column of Table 6 , also based on Table 4, showing average real consumption per person in constant 1992-1993 prices. Over the 2 decades average real expenditure per person in quintile 1 increased (in constant 1992-1993 prices) by KN1,464. For quintile 5 it was 10 times this amount, at KN14,618. The absolute increase for quintile 5 far exceeded that for quintile 4, which exceeded quintile 3 , and so forth. Overall, the poor gained in real terms, but the rich gained much more.

10 The literature on inequality refers to this concept as absolute inequality, whereas standard measures, such as quintile shares or the Gini coefficient focus on relative inequality. An increase in relative inequality necessarily implies an increase in absolute inequality, but not vice versa. 
Table 4: Average Level of Real Expenditure by Quintile Group (CPI deflator, 1992-1993 = 1)

\begin{tabular}{lccccc}
\hline Quintile Group & $\begin{array}{c}1992-1993 \\
\text { (LECS 1) }\end{array}$ & $\begin{array}{c}1997-1998 \\
\text { (LECS 2) }\end{array}$ & $\begin{array}{c}2002-2003 \\
\text { (LECS 3) }\end{array}$ & $\begin{array}{c}2007-2008 \\
\text { (LECS 4) }\end{array}$ & $\begin{array}{c}2012-2013 \\
\text { (LECS 5) }\end{array}$ \\
\hline Quintile 1 (poorest) & 4,848 & 5,244 & 4,834 & 5,867 & 6,312 \\
Quintile 2 & 7,139 & 8,070 & 7,124 & 8,904 & 9,507 \\
Quintile 3 & 9,229 & 10,725 & 9,363 & 11,681 & 12,675 \\
Quintile 4 & 12,180 & 14,624 & 12,668 & 16,140 & 17,172 \\
Quintile 5 (richest) & 22,472 & 31,968 & 25,963 & 34,761 & 37,090 \\
\hline Mean & 11,170 & 14,123 & 11,985 & 15,468 & 16,549 \\
\hline
\end{tabular}

$\mathrm{CPI}=$ consumer price index, LECS = Lao Expenditure and Consumption Survey.

Note: Units of real household expenditures are kip per person per month, 1992-1993 prices.

Source: Authors' calculations using LECS and consumer price index data from Lao Statistics Bureau.

\section{Table 5: Percent Change in Real Expenditure by Quintile Group} (CPI deflator, \%)

\begin{tabular}{lcccc}
\hline Quintile Group & $1992-1993$ to & $1997-1998$ to & $2002-2003$ to & $2007-2008$ to \\
$1997-1998$ & $2002-2003$ & $2007-2008$ & $2012-2013$ \\
\hline Quintile 1 (poorest) & 8.2 & -7.8 & 21.4 & 7.6 \\
Quintile 2 & 13.0 & -11.7 & 25.0 & 6.8 \\
Quintile 3 & 16.2 & -12.7 & 24.8 & 8.5 \\
Quintile 4 & 20.1 & -13.4 & 27.4 & 6.4 \\
Quintile 5 (richest) & 42.3 & -18.8 & 33.9 & 6.7 \\
\hline Mean & 26.4 & -15.1 & 29.1 & 7.0 \\
\hline
\end{tabular}

$\mathrm{CPI}=$ = consumer price index.

Source: Authors' calculations using LECS and consumer price index data from Lao Statistics Bureau.

Table 6: Change in Real Expenditure, 1992-1993 to 2012-2013 (CPI deflator)

\begin{tabular}{lcc}
\hline Quintile Group & $\begin{array}{c}\text { Proportional } \\
\text { Change } \\
(\%)\end{array}$ & $\begin{array}{c}\text { Absolute } \\
\text { Change } \\
(\mathrm{KN}, 1992-1993 \text { prices) }\end{array}$ \\
\hline Quintile 1 (poorest) & 30.2 & 1,464 \\
Quintile 2 & 33.2 & 2,368 \\
Quintile 3 & 37.3 & 3,446 \\
Quintile 4 & 41.0 & 4,992 \\
Quintile 5 (richest) & 65.0 & 14,618 \\
\hline Mean & 48.2 & 5,379 \\
\hline
\end{tabular}

$\mathrm{CPI}=$ consumer price index, $\mathrm{KN}=$ kip.

Note: Calculated from Table 4

Source: Authors' calculations using LECS and consumer price index data from Lao Statistics Bureau. 
This pattern is revealed even more vividly by Figure 3, which shows the percentage changes (Figure 3.a) and absolute changes (Figure 3.b) of real income across this 20-year interval, arranged by centile group. Centile 1 (left side of the horizontal axis) is the poorest and centile 100 (right side) is the richest." Focusing first on proportional changes, with the possible exception of the poorest urban centile (urban centile 1), every centile group gained. Moreover, the poorest rural households fared proportionately better than the poorest urban households. But moving across the distribution, proportional gains were larger for higher centile groups in both rural and urban areas. The really large gains, both proportional and absolute, were enjoyed by the top $2 \%$ to $3 \%$ of the distribution and this was true in both rural and urban areas.

\section{Figure 3: Changes in Real Expenditures per Person by Centile Group,} $1992-1993$ to 2012-2013

\section{a. Percentage changes}

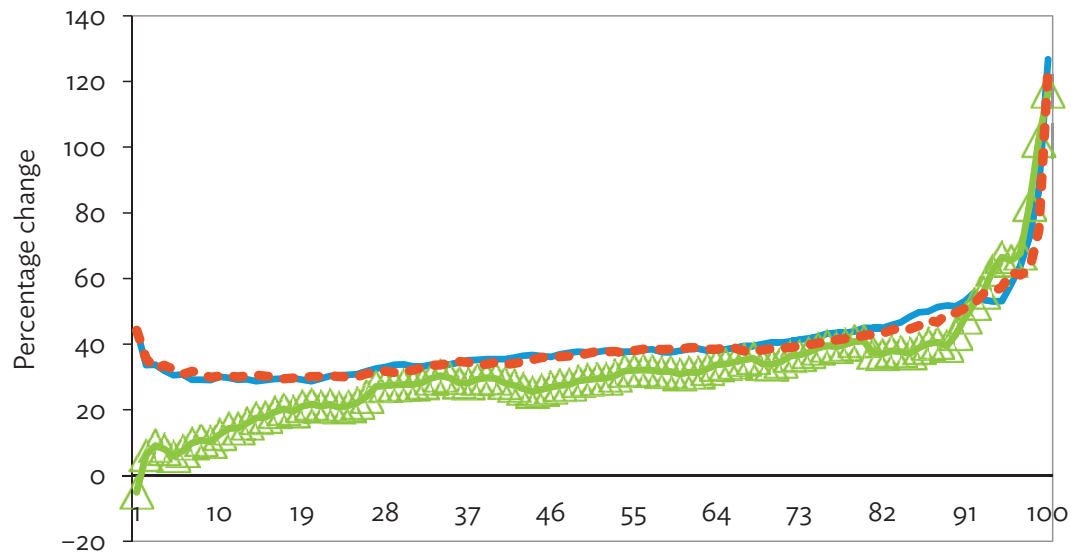

b. Absolute changes

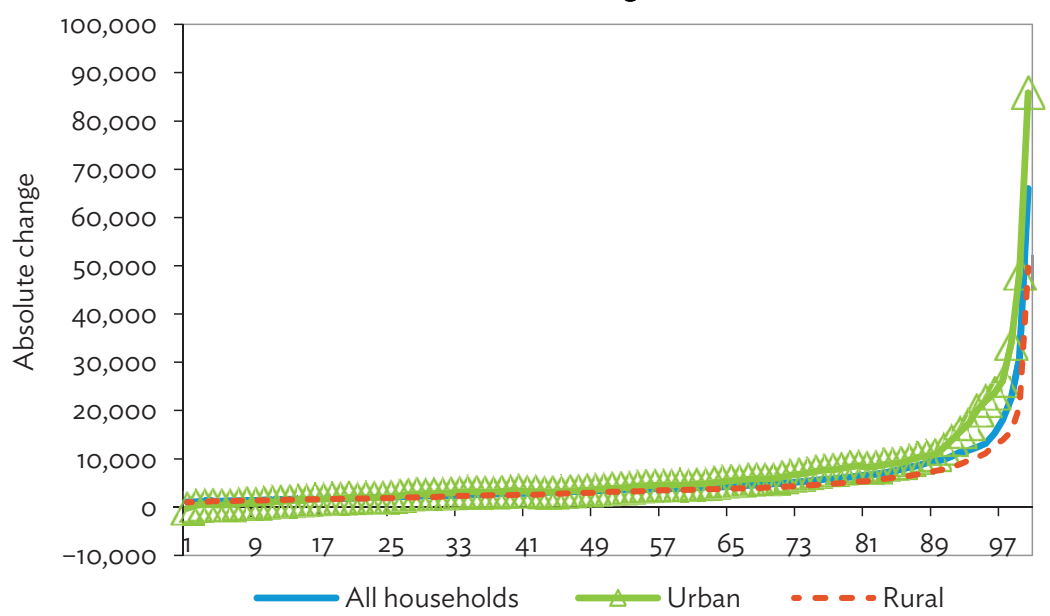

Source: Authors' calculations using LECS and consumer price index data from Lao Statistics Bureau.

11 In comparing the distributions across years, it must be remembered that the households found in a particular centile group in, say, the first year are not necessarily the same individual households as those belonging to that centile group in the second year. 
Standard measures of inequality and poverty incidence confirm the overall story conveyed by these calculations. Table 7 and Figure 4 summarize the LECS data on the level of the Gini coefficient of inequality over this 20-year period. With the partial exception of a high value of the coefficient in 1997-1998 (LECS 2), the Gini coefficient increased continuously over the 2 decades covered by these surveys. This is true at the national level and within both rural and urban areas. The absolute level of the coefficient is consistently higher in urban than in rural areas, but its level increased steadily in both, again with the partial exception of an abnormally high level in 1997-1998. Similar findings apply for each of the four major regions of the country. Over the 20-year period, the Gini coefficient increased in all regions. In the most recent 5-year period, 2008-2008 to 2012-2013, the only region in which inequality increased was the South. ${ }^{12}$ Finally, Table 8 shows a long-term increase in inequality within every one of the 17 provinces, although in some provinces 1997-1998 was an outlier to the pattern of steadily increasing inequality, as it is at the national level.

Table 7: Gini Coefficient by Region and Rural-Urban Location

\begin{tabular}{lccccc}
\hline & $1992-1993$ & $1997-1998$ & $2002-2003$ & $2007-2008$ & $2012-2013$ \\
\hline Vientiane & 0.30 & 0.37 & 0.36 & 0.38 & 0.38 \\
North & 0.27 & 0.35 & 0.31 & 0.35 & 0.32 \\
Center & 0.32 & 0.33 & 0.31 & 0.34 & 0.34 \\
South & 0.32 & 0.32 & 0.31 & 0.32 & 0.37 \\
& & & & & \\
Rural & 0.29 & 0.32 & 0.31 & 0.33 & 0.33 \\
Urban & 0.31 & 0.38 & 0.35 & 0.36 & 0.38 \\
\hline National & 0.31 & 0.35 & 0.33 & 0.36 & 0.37 \\
\hline
\end{tabular}

Note: The Gini coefficient varies from 0 to 1, higher values indicating greater inequality.

Source: Authors' calculations using LECS data from Lao Statistics Bureau.

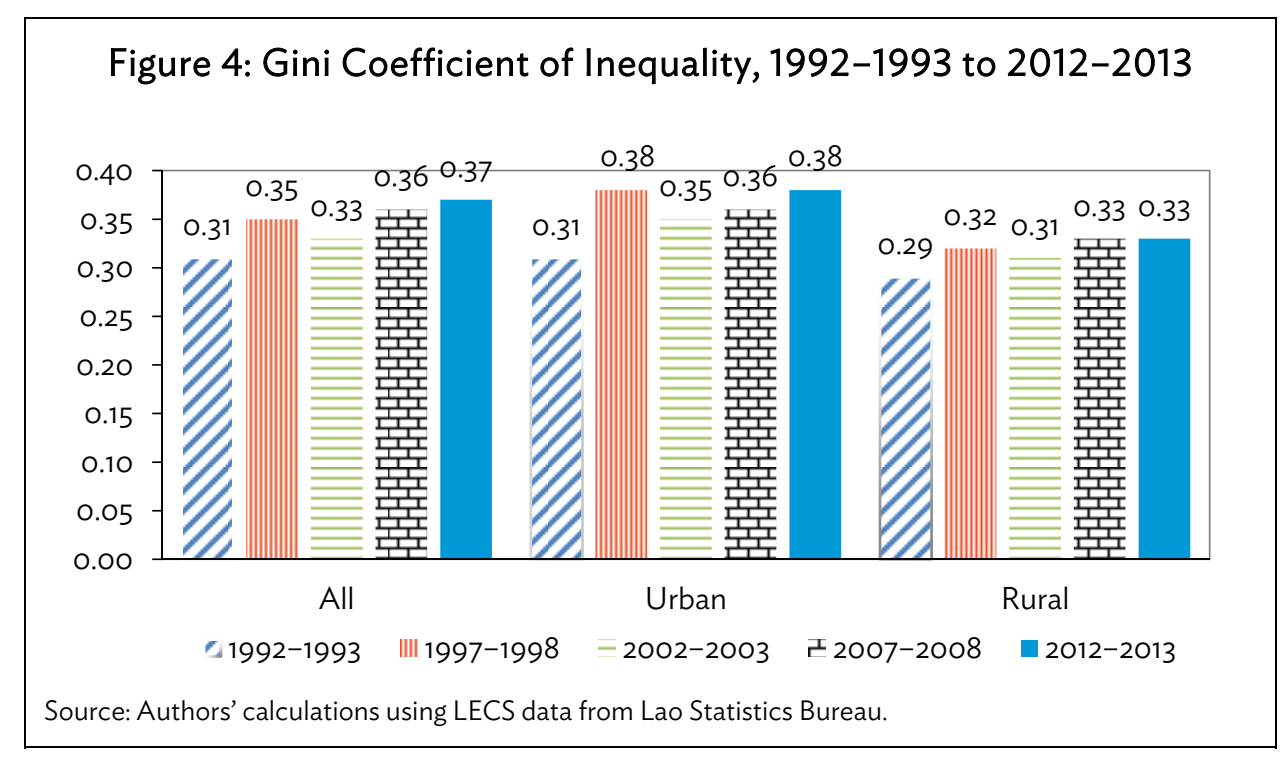

12 Mining exports dominate the Southern economy and this may be a driver of the most recent increase in inequality observable there. This recent period also coincides with large increases in foreign direct investment in mining and exports of minerals from the South. Nevertheless, the South did not account for the increase in national inequality in any previous 5-year interval, nor did any other single region. It seems possible that the causes of rising inequality may have varied over time. 
Table 8: Gini Coefficient by Province

\begin{tabular}{lccccc}
\hline Province & $1992-1993$ & $1997-1998$ & $2002-2003$ & $2007-2008$ & $2012-2013$ \\
\hline Vientiane capital & 0.28 & 0.36 & 0.36 & 0.38 & 0.38 \\
Phongsaly & 0.19 & 0.29 & 0.22 & 0.30 & 0.27 \\
Luangnamtha & 0.23 & 0.32 & 0.25 & 0.30 & 0.36 \\
Oudomxay & 0.25 & 0.38 & 0.25 & 0.31 & 0.30 \\
Bokeo & 0.25 & 0.31 & 0.29 & 0.30 & 0.29 \\
Luangprabang & 0.29 & 0.35 & 0.32 & 0.31 & 0.31 \\
Huaphanh & 0.27 & 0.36 & 0.29 & 0.28 & 0.28 \\
Xayabury & 0.26 & 0.39 & 0.35 & 0.42 & 0.34 \\
Xiengkhuang & 0.28 & 0.35 & 0.32 & 0.38 & 0.35 \\
Vientiane & 0.29 & 0.37 & 0.32 & 0.32 & 0.31 \\
Borikhamxay & 0.25 & 0.32 & 0.28 & 0.34 & 0.36 \\
Khammuane & 0.27 & 0.36 & 0.29 & 0.31 & 0.30 \\
Savannakhet & 0.28 & 0.33 & 0.31 & 0.34 & 0.34 \\
Saravane & 0.23 & 0.32 & 0.27 & 0.30 & 0.34 \\
Sekong & 0.28 & 0.32 & 0.31 & 0.38 & 0.40 \\
Champasack & 0.28 & 0.36 & 0.30 & 0.29 & 0.34 \\
Attapeu & 0.26 & 0.30 & 0.29 & 0.32 & 0.33 \\
\hline National & 0.31 & 0.35 & 0.33 & 0.36 & 0.37 \\
\hline Source & 0.36 & & \\
\hline
\end{tabular}

Source: Authors' calculations using LECS data from Lao Statistics Bureau.

The LECS surveys identify 50 ethnic groups in the Lao PDR. They can be summarized into the four major categories listed in Table $9 .^{13}$ The surveys make it possible to identify ethnic categories only for the years 2002-2003 (LECS 3), 2007-2008 (LECS 4), and 2012-2013 (LECS 5). Over the decade covered by these data the dominant Lao-Tai group (64\% of the population) has consistently enjoyed the highest average level of expenditure per person. The level of inequality within this group is the highest of the four categories. Over this decade, the increase in average expenditure per person of the Lao-Tai group was equal to the population average. Inequality increased among all four ethnic groups, as measured by the Gini coefficient, but the increase within the majority Lao-Tai ethnic group was the smallest. Figure 5 summarizes these changes within a format similar to Figure 3. The three minority ethnic groups are aggregated into a single category, labeled "minority." The increase in expenditures per person was heavily concentrated in the top few centile groups within both the Lao-Tai and minority categories, but the concentration at the top was even higher within the minority groups than for the Lao-Tai.

13 The mapping from the 50 LECS categories into these four is: LECS 1- 8 = Lao-Tai; LECS 9-40 = Mon-Khmer, LECS 4147 = Chinese-Tibetan, LECS 48-50 = Mon-Mien (Lao Statistics Bureau. Survey Guide Book, 2002-2003, 2007-2008, and 2012-2013. Vientiane). 
Table 9: Inequality by Ethnic Group

\begin{tabular}{|c|c|c|c|c|c|c|c|}
\hline \multirow[b]{2}{*}{ Ethnic Group } & \multirow{2}{*}{$\begin{array}{c}\text { Population } \\
\text { Share (\%) } \\
2012- \\
2013 \\
\text { (LECS 5) }\end{array}$} & \multicolumn{3}{|c|}{ Mean Real Consumption per Person } & \multicolumn{3}{|c|}{ Gini Coefficient } \\
\hline & & $\begin{array}{c}2002- \\
2003 \\
\text { (LECS 3) }\end{array}$ & $\begin{array}{c}2012- \\
2013 \\
\text { (LECS 5) }\end{array}$ & $\begin{array}{c}\text { Percent } \\
\text { Change: } \\
\text { LECS } 3 \text { to } \\
\text { LECS } 5\end{array}$ & $\begin{array}{c}2002- \\
2003 \\
(\text { LECS } 3)\end{array}$ & $\begin{array}{c}2012- \\
2013 \\
\text { (LECS 5) }\end{array}$ & $\begin{array}{c}\text { Change: } \\
\text { LECS } 3 \text { to } \\
\text { LECS }\end{array}$ \\
\hline Lao-Tai & 63.6 & 13,730 & 18,991 & 38 & 0.346 & 0.362 & 0.016 \\
\hline Mon-Khmer & 23.6 & 8,176 & 11,651 & 42 & 0.272 & 0.302 & 0.030 \\
\hline Chinese-Tibetan & 5.0 & 9,230 & 14,441 & 56 & 0.247 & 0.284 & 0.037 \\
\hline Mon-Mien & 7.8 & 9,127 & 12,267 & 34 & 0.294 & 0.324 & 0.030 \\
\hline Total population & 100.0 & 11,985 & 16,549 & 38 & 0.334 & 0.366 & 0.032 \\
\hline
\end{tabular}

LECS = Lao Expenditure and Consumption Survey.

Notes: Units of real consumption are kip per person per month, 1992-1993 prices. "Ethnic group" means the ethnicity of the head of the household. Data on ethnicity are not available for 1992-1993 (LECS 1) and 1997-1998 (LECS 2).

Source: Authors' calculations using LECS data from Lao Statistics Bureau.

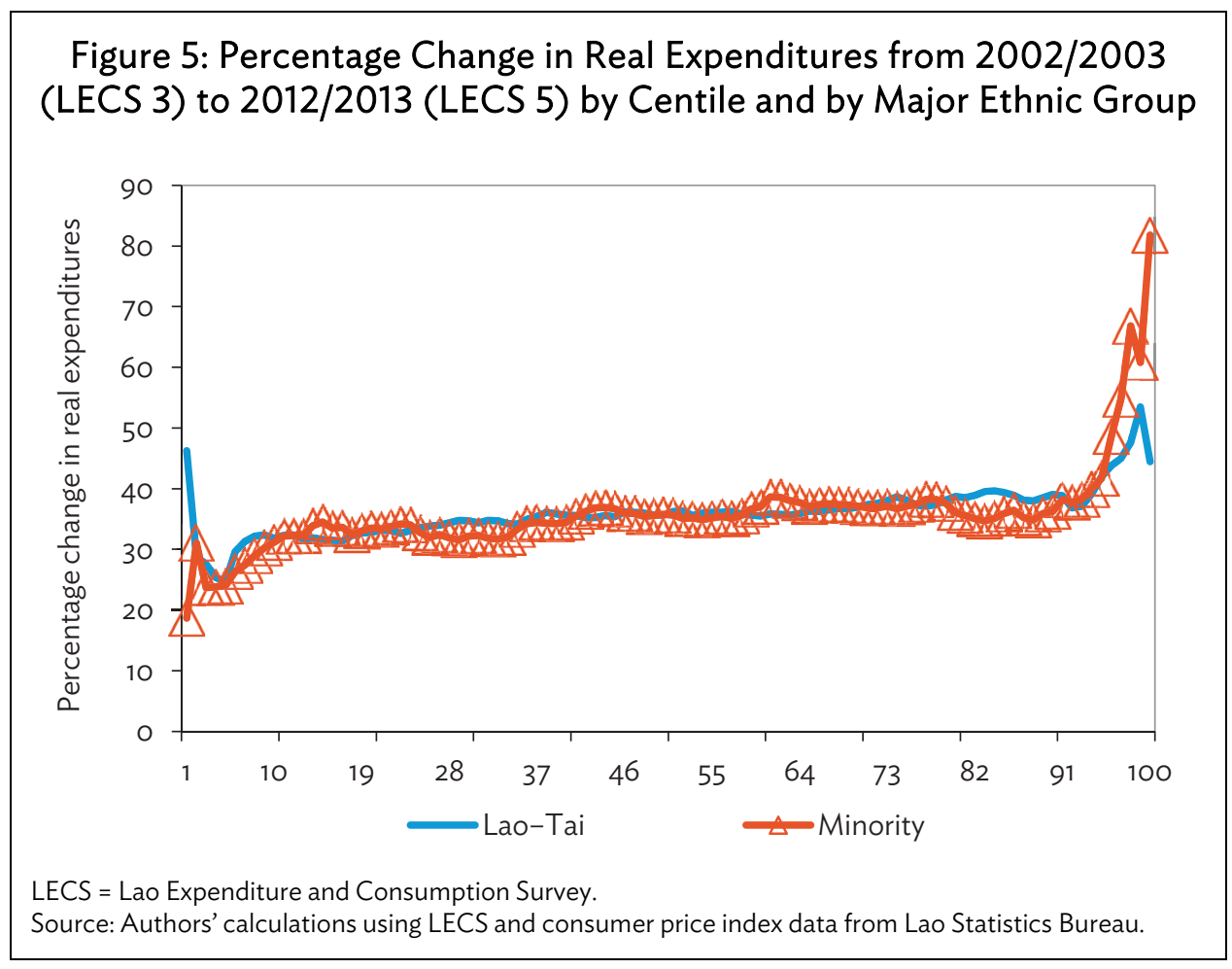

In contrast to this overall picture of rising inequality, Table 10 and Figure 6 show that measured poverty incidence declined steadily over the 2 decades. This is true at the national level, within both rural and urban areas and within every region. Poverty incidence has been consistently higher in rural than in urban areas, but has declined steadily in both. Again, the message is that the poor became better-off in absolute terms, but lost ground relative to all other income groups. The richest few centiles benefited hugely. This basic pattern is evident throughout the country. 
Table 10: Poverty Incidence, 1992-1993 to 2012-2013

\begin{tabular}{lccccc}
\hline & $1992-1993$ & $1997-1998$ & $2002-2003$ & $2007-2008$ & $2012-2013$ \\
\hline Rural & 51.8 & 42.5 & 37.6 & 31.7 & 28.6 \\
Urban & 26.5 & 22.1 & 19.7 & 17.4 & 10.0 \\
Vientiane & 33.6 & 13.5 & 16.7 & 15.2 & 5.9 \\
North & 51.6 & 47.3 & 37.9 & 32.5 & 25.8 \\
Central & 45.0 & 39.4 & 35.4 & 29.8 & 23.3 \\
South & 45.7 & 39.8 & 32.6 & 22.8 & 29.2 \\
\hline National & 46.0 & 39.1 & 33.5 & 27.6 & 23.2 \\
\hline
\end{tabular}

Note: 2012-2013 data are the authors' preliminary estimates, based on 2012-2013 LECS data and preliminary poverty lines. These poverty estimates are subject to possible revision.

Source: Data from Lao Statistics Bureau.

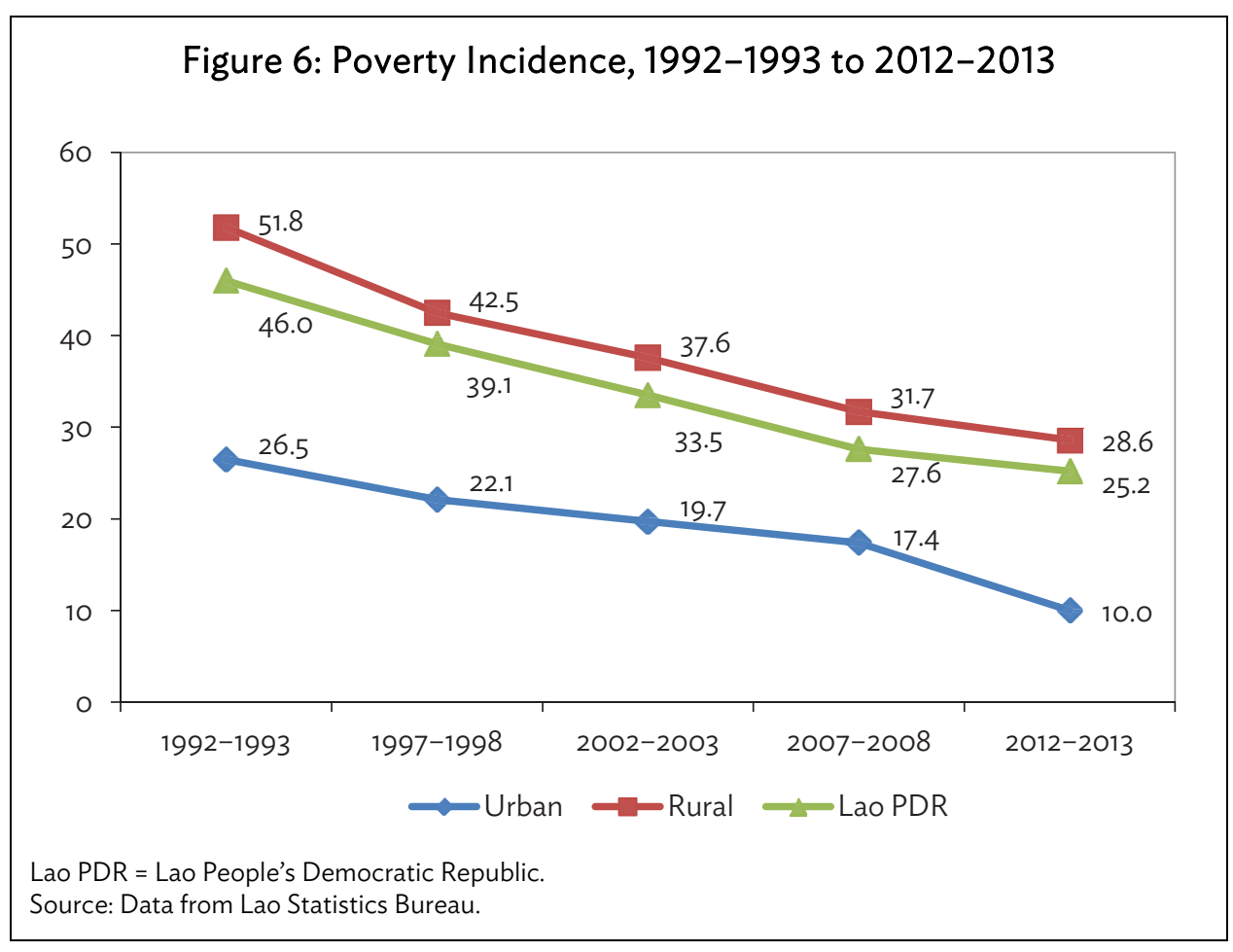

\section{SIGNIFICANCE OF THE RISE IN INEQUALITY}

\section{A. Was the Increase in Inequality Statistically Significant?}

It is easily overlooked that measures of inequality and poverty are based on sample surveys covering only a small proportion of the population. They produce estimates of the population values of inequality and poverty indicators, but those estimates necessarily entail errors. First, there are measurement errors that occur during the collection of the raw, household-level data. Second, there may be sample bias if the sample is nonrepresentative of the population. Both of these sources of error imply that the expected value of the sample-based estimate may not be equal to the true population value. Statisticians go to great lengths to minimize both of these sources of error, as is done in the case of the LECS surveys. But even if these two sources of error were eliminated, there remains an 
unavoidable third source of error: sample error arising from the small sample used to estimate the population value. ${ }^{14}$ The sample-based estimates are necessarily associated with a standard error, measuring the uncertainty about the reliability of the sample estimate as an indicator of the true population value. When two sample-based estimates are compared over time, the standard error of the difference between the two estimates must be considered in assessing whether the observed difference might reasonably be attributed to chance. It is possible, for example, that a change in measured inequality could be observed purely because of random sample error, when true inequality did not change at all. This could happen even if the first two sources of error outlined abovemeasurement error and sample bias-were entirely absent. What is the probability that random sample error accounts for the observed increases in inequality described above?

In the analysis that follows, we review the changes in inequality measures, first across the decade 1992-1993 to 2002-2003 (LECS 1 to LECS 3), then the decade 2002-2003 to 2012-2013 (LECS 3 to LECS 5), and finally the full 2 decades 1992-1993 to 2012-2013 (LECS 1 to LECS 5). The sample-based estimates indicate that inequality increased across each of these intervals. But are the estimated increases significantly different from zero? Inequality measures are compared at the national level, meaning that it covers all households in the sample, and within both rural and urban areas. For each of these three levels, we compare Gini coefficients and also a member of the class of Generalized Entropy (GE) measures, the GE(1) measure, also known as the Theil $T$ index. The importance of the latter is that (along with all other members of the GE class, it has properties that are useful in decomposing inequality and changes in it, which will be important in following sections. This gives six sets of measures and the results are summarized in Tables 11 to 13.

Table 11: Changes in Measured Inequality, 1992-1993 to 2002-2003

\begin{tabular}{|c|c|c|c|c|c|}
\hline Measure of Inequality & $\begin{array}{c}1992-1993 \\
\text { (LECS 1) }\end{array}$ & $\begin{array}{c}2002-2003 \\
\text { (LECS 3) }\end{array}$ & Difference & $p$-value & $\begin{array}{l}\text { Percent } \\
\text { Change }\end{array}$ \\
\hline Gini Coefficient (national) & $\begin{array}{c}0.311 \\
(0.009)\end{array}$ & $\begin{array}{c}0.347 \\
(0.007)\end{array}$ & $\begin{array}{l}0.036^{* * *} \\
{[0.011]}\end{array}$ & 0.001 & 12 \\
\hline Gini Coefficient (urban) & $\begin{array}{c}0.301 \\
(0.010)\end{array}$ & $\begin{array}{r}0.350 \\
(0.011)\end{array}$ & $\begin{array}{l}0.049^{* * *} \\
{[0.015]}\end{array}$ & 0.001 & 16 \\
\hline Gini Coefficient (rural) & $\begin{array}{c}0.280 \\
(0.010)\end{array}$ & $\begin{array}{c}0.307 \\
(0.006)\end{array}$ & $\begin{array}{c}0.027^{* *} \\
{[0.012]}\end{array}$ & 0.021 & 10 \\
\hline GE(1), Theil's T (national) & $\begin{array}{c}0.171 \\
(0.010)\end{array}$ & $\begin{array}{c}0.231 \\
(0.012)\end{array}$ & $\begin{array}{l}0.060^{* * *} \\
{[0.016]}\end{array}$ & 0.000 & 35 \\
\hline GE(1), Theil's T (urban) & $\begin{array}{c}0.158 \\
(0.014)\end{array}$ & $\begin{array}{c}0.233 \\
(0.022)\end{array}$ & $\begin{array}{l}0.075^{* * *} \\
{[0.026]}\end{array}$ & 0.004 & 48 \\
\hline GE(1), Theil's T (rural) & $\begin{array}{c}0.137 \\
(0.009) \\
\end{array}$ & $\begin{array}{c}0.178 \\
(0.009)\end{array}$ & $\begin{array}{l}0.041^{* * *} \\
{[0.013]}\end{array}$ & 0.002 & 30 \\
\hline
\end{tabular}

GE = generalized entropy, LECS = Lao Expenditure and Consumption Survey.

Notes:

1. All estimates are computed using probability weights calculated by taking the inverse of the sampling fraction. Calculations are weighted by survey weights $X$ household size.

2. Linearized standard errors of point estimates in round parentheses; standard errors of changes in square parentheses. Standard errors for Gini coefficients are based on the STATA code of Jenkins (2008), which uses the method of Kovacevic and Binder (1997). Standard errors for Theil's T index are based on the STATA command of Biewen and Jenkins (2006), which uses the method of Woodruff (1971).

3. ${ }^{* * *}, * *$, and ${ }^{*}$ indicate significance at $1 \%, 5 \%$, and $10 \%$ levels, respectively. Source: Authors' calculations using LECS data from Lao Statistics Bureau.

14 The LECS 1 (1992-1993) survey covered 2,937 households out of a population of 702,000 households and 4.4 million individuals. Subsequent LECS surveys covered between 8,200 and 8,900 households. By 2013, the total population was 1.14 million households and 6.5 million individuals. 
Table 12: Changes in Measured Inequality 2002-2003 to 2012-2013

\begin{tabular}{|c|c|c|c|c|c|}
\hline Measure of Inequality & $\begin{array}{c}2002-2003 \\
\text { (LECS 3) }\end{array}$ & $\begin{array}{c}2012-2013 \\
\text { (LECS 5) }\end{array}$ & Difference & $p$-value & $\begin{array}{l}\text { Percent } \\
\text { Change }\end{array}$ \\
\hline Gini coefficient (national) & $\begin{array}{c}0.347 \\
(0.007)\end{array}$ & $\begin{array}{c}0.364 \\
(0.008)\end{array}$ & $\begin{array}{c}0.018^{*} \\
{[0.010]}\end{array}$ & 0.085 & 5 \\
\hline Gini coefficient (urban) & $\begin{array}{r}0.350 \\
(0.011)\end{array}$ & $\begin{array}{c}0.375 \\
(0.012)\end{array}$ & $\begin{array}{c}0.025 \\
{[0.016]}\end{array}$ & 0.119 & 7 \\
\hline Gini coefficient (rural) & $\begin{array}{c}0.307 \\
(0.006)\end{array}$ & $\begin{array}{c}0.329 \\
(0.009)\end{array}$ & $\begin{array}{l}0.022^{* *} \\
{[0.011]}\end{array}$ & 0.040 & 7 \\
\hline GE(1), Theil's T (national) & $\begin{array}{c}0.231 \\
(0.012)\end{array}$ & $\begin{array}{c}0.258 \\
(0.013)\end{array}$ & $\begin{array}{c}0.028 \\
{[0.018]}\end{array}$ & 0.124 & 12 \\
\hline GE(1), Theil's T (urban) & $\begin{array}{c}0.233 \\
(0.022)\end{array}$ & $\begin{array}{c}0.268 \\
(0.019)\end{array}$ & $\begin{array}{c}0.035 \\
{[0.022]}\end{array}$ & 0.107 & 15 \\
\hline GE(1), Theil's T (rural) & $\begin{array}{c}0.178 \\
(0.009) \\
\end{array}$ & $\begin{array}{r}0.209 \\
(0.013) \\
\end{array}$ & $\begin{array}{r}0.031^{*} \\
{[0.016]}\end{array}$ & 0.055 & 17 \\
\hline
\end{tabular}

GE = generalized entropy, LECS = Lao Expenditure and Consumption Survey.

Notes:

1. All estimates are computed using probability weights calculated by taking the inverse of the sampling fraction. Calculations are weighted by survey weights $X$ household size.

2. Linearized standard errors of point estimates in round parentheses; standard errors of changes in square parentheses. Standard errors for Gini coefficients are based on the STATA code of Jenkins (2008), which uses the method of Kovacevic and Binder (1997). Standard errors for Theil's T index are based on the STATA command of Biewen and Jenkins (2006), which uses the method of Woodruff (1971).

3. ***, ** and ${ }^{*}$ indicate significance at $1 \%, 5 \%$, and $10 \%$ levels, respectively.

Source: Authors' calculations using LECS data from Lao Statistics Bureau.

Table 13: Changes in Measured Inequality 1992-93 to 2012-13

\begin{tabular}{|c|c|c|c|c|c|}
\hline Measure of Inequality & $\begin{array}{c}1992-1993 \\
\text { (LECS 1) }\end{array}$ & $\begin{array}{c}2012-2013 \\
\text { (LECS 5) }\end{array}$ & Difference & $p$-value & $\begin{array}{l}\text { Percent } \\
\text { Change }\end{array}$ \\
\hline Gini coefficient (national) & $\begin{array}{c}0.311 \\
(0.009)\end{array}$ & $\begin{array}{c}0.364 \\
(0.008)\end{array}$ & $\begin{array}{l}0.054^{* * *} \\
{[0.012]}\end{array}$ & 0.000 & 17 \\
\hline Gini coefficient (urban) & $\begin{array}{c}0.301 \\
(0.010)\end{array}$ & $\begin{array}{c}0.375 \\
(0.012)\end{array}$ & $\begin{array}{l}0.074^{* * *} \\
{[0.015]}\end{array}$ & 0.000 & 25 \\
\hline Gini coefficient (rural) & $\begin{array}{c}0.280 \\
(0.010)\end{array}$ & $\begin{array}{c}0.329 \\
(0.009)\end{array}$ & $\begin{array}{l}0.049^{* * *} \\
{[0.013]}\end{array}$ & 0.000 & 17 \\
\hline GE(1), Theil's T (national) & $\begin{array}{c}0.171 \\
(0.010)\end{array}$ & $\begin{array}{c}0.258 \\
(0.013)\end{array}$ & $\begin{array}{l}0.087^{* * *} \\
{[0.016]}\end{array}$ & 0.000 & 51 \\
\hline GE(1), Theil's T (urban) & $\begin{array}{c}0.158 \\
(0.014)\end{array}$ & $\begin{array}{c}0.268 \\
(0.019)\end{array}$ & $\begin{array}{l}0.110^{* * *} \\
{[0.021]}\end{array}$ & 0.000 & 70 \\
\hline GE(1), Theil's T (rural) & $\begin{array}{c}0.137 \\
(0.009)\end{array}$ & $\begin{array}{c}0.209 \\
(0.013)\end{array}$ & $\begin{array}{l}0.072^{* * *} \\
{[0.016]}\end{array}$ & 0.000 & 52 \\
\hline
\end{tabular}

GE = generalized entropy, LECS = Lao Expenditure and Consumption Survey.

Notes:

1. All estimates are computed using probability weights calculated by taking the inverse of the sampling fraction. Calculations are weighted by survey weights $X$ household size.

2. Linearized standard errors of point estimates in round parentheses; standard errors of changes in square parentheses. Standard errors for Gini coefficients are based on the STATA code of Jenkins (2008), which uses the method of Kovacevic and Binder (1997). Standard errors for Theil's T index are based on the STATA command of Biewen and Jenkins (2006), which uses the method of Woodruff (1971).

3. ${ }^{* * *}, * *$, and ${ }^{*}$ indicate significance at $1 \%, 5 \%$, and $10 \%$ levels, respectively.

Source: Authors' calculations using LECS data from Lao Statistics Bureau. 
The findings provide overall support for the hypothesis that the true population levels of inequality did indeed increase. First, from Table 11, the measured increase in inequality observed over the decade 1992-1993 to 2002-2003 (LECS 1 to LECS 3) was, in all cases, statistically significant at the $95 \%$ confidence level. This can be seen from the fourth column of the table. A $p$-value less than or equal to 0.05 indicates significance at the $95 \%$ confidence level and a value less than or equal to 0.01 indicates significance at the $99 \%$ confidence level. ${ }^{15}$ In all cases but one (the Gini coefficient in rural areas) the $p$-value is less than 0.01 , meaning that (except in this one case) we can be $99 \%$ confident that the true population value did increase. Second, from Table 12, the measured increases in inequality over the decade 2002-2003 to 2012-2013 (LECS 3 to LECS 5) were somewhat smaller than those seen over the previous decade and none of the six measures increased significantly at the 95\% confidence level, except the Gini coefficient in rural areas. Third, from Table 13, over the 2 decades 1992-1993 (LECS 1) to 2012-2013 (LECS 5), all six measures increased significantly at confidence levels of $99 \%$ or better.

Finally, in Table 14 we apply this methodology to the estimated province-level values of the Gini coefficient over the full 2-decade period. Sample sizes are relatively small in some of these provinces, raising the standard errors of the estimates. The Gini coefficient increased in all 17 provinces and the increase was statistically significant at the 95\% confidence level or above in seven of these provinces. When this exercise is repeated with the Theil $T$ index (detailed results not shown, for brevity), an increase in inequality is recorded in 15 out of the 17 provinces, significant at the $95 \%$ confidence in eight provinces, with very small, nonsignificant declines in two.

The findings confirm that a genuine increase in inequality has occurred within the Lao PDR. The sample-based increases in measured inequality cannot reasonably be attributed to sample error.

Table 14: Changes in Gini Coefficient by Province, 1992-1993 to 2012-2013

\begin{tabular}{|c|c|c|c|c|c|}
\hline Province & $\begin{array}{c}1992-1993 \\
\text { (LECS 1) }\end{array}$ & $\begin{array}{c}2012-2013 \\
\text { (LECS 5) }\end{array}$ & Difference & $p$-value & $\begin{array}{l}\text { Percent } \\
\text { Change }\end{array}$ \\
\hline Vientiane capital & $\begin{array}{c}0.283 \\
(0.013)\end{array}$ & $\begin{array}{c}0.376 \\
(0.015)\end{array}$ & $\begin{array}{c}0.093^{* * *} \\
{[0.020]}\end{array}$ & 0.000 & 33 \\
\hline Phongsaly & $\begin{array}{c}0.185 \\
(0.026)\end{array}$ & $\begin{array}{c}0.272 \\
(0.031)\end{array}$ & $\begin{array}{c}0.087^{* *} \\
{[0.040]}\end{array}$ & 0.031 & 47 \\
\hline Luangnamta & $\begin{array}{c}0.231 \\
(0.069)\end{array}$ & $\begin{array}{c}0.360 \\
(0.039)\end{array}$ & $\begin{array}{c}0.129 \\
{[0.079]}\end{array}$ & 0.103 & 56 \\
\hline Oudomxay & $\begin{array}{c}0.250 \\
(0.017)\end{array}$ & $\begin{array}{c}0.296 \\
(0.039)\end{array}$ & $\begin{array}{c}0.046 \\
{[0.043]}\end{array}$ & 0.282 & 18 \\
\hline Bokeo & $\begin{array}{c}0.246 \\
(0.007)\end{array}$ & $\begin{array}{c}0.289 \\
(0.030)\end{array}$ & $\begin{array}{c}0.042 \\
{[0.031]}\end{array}$ & 0.167 & 17 \\
\hline Luangphrabang & $\begin{array}{c}0.290 \\
(0.049)\end{array}$ & $\begin{array}{c}0.315 \\
(0.013)\end{array}$ & $\begin{array}{c}0.025 \\
{[0.050]}\end{array}$ & 0.624 & 9 \\
\hline Huaphanh & $\begin{array}{c}0.265 \\
(0.024)\end{array}$ & $\begin{array}{c}0.277 \\
(0.028)\end{array}$ & $\begin{array}{c}0.012 \\
{[0.037]}\end{array}$ & 0.737 & 5 \\
\hline Xayaboury & $\begin{array}{c}0.263 \\
(0.026)\end{array}$ & $\begin{array}{c}0.347 \\
(0.027)\end{array}$ & $\begin{array}{c}0.084^{* *} \\
{[0.037]}\end{array}$ & 0.025 & 32 \\
\hline Xiengkhu & $\begin{array}{c}0.275 \\
(0.029) \\
\end{array}$ & $\begin{array}{c}0.354 \\
(0.019) \\
\end{array}$ & $\begin{array}{c}0.079^{* *} \\
{[0.035]}\end{array}$ & 0.023 & 29 \\
\hline
\end{tabular}

continued on next page

15 We are testing the null hypothesis that the true population value did not change. A $p$-value of 0.05 means that this hypothesis can be rejected with 95\% confidence, because if the null hypothesis was true, the observed sample-based difference could have occurred only with a probability of 0.05 . 
Table 14 continued

\begin{tabular}{|c|c|c|c|c|c|}
\hline Province & $\begin{array}{l}\text { 1992-1993 } \\
\text { (LECS 1) }\end{array}$ & $\begin{array}{l}2012-2013 \\
\text { (LECS 5) }\end{array}$ & Difference & $p$-value & $\begin{array}{l}\text { Percent } \\
\text { Change }\end{array}$ \\
\hline Vientiane & $\begin{array}{c}0.294 \\
(0.022)\end{array}$ & $\begin{array}{c}0.314 \\
(0.017)\end{array}$ & $\begin{array}{c}0.021 \\
{[0.028]}\end{array}$ & 0.464 & 7 \\
\hline Borikham & $\begin{array}{c}0.251 \\
(0.029)\end{array}$ & $\begin{array}{c}0.364 \\
(0.032)\end{array}$ & $\begin{array}{c}0.113^{* * *} \\
{[0.043]}\end{array}$ & 0.009 & 45 \\
\hline Khammuan & $\begin{array}{c}0.269 \\
(0.038)\end{array}$ & $\begin{array}{r}0.298 \\
(0.031)\end{array}$ & $\begin{array}{c}0.029 \\
{[0.049]}\end{array}$ & 0.553 & 11 \\
\hline Savannak & $\begin{array}{c}0.279 \\
(0.023)\end{array}$ & $\begin{array}{c}0.343 \\
(0.029)\end{array}$ & $\begin{array}{c}0.064^{*} \\
{[0.037]}\end{array}$ & 0.086 & 23 \\
\hline Saravane & $\begin{array}{c}0.226 \\
(0.017)\end{array}$ & $\begin{array}{c}0.345 \\
(0.023)\end{array}$ & $\begin{array}{c}0.118^{* * *} \\
{[0.029]}\end{array}$ & 0.000 & 52 \\
\hline Sekong & $\begin{array}{c}0.284 \\
(0.026)\end{array}$ & $\begin{array}{c}0.399 \\
(0.049)\end{array}$ & $\begin{array}{c}0.115^{* *} \\
{[0.056]}\end{array}$ & 0.040 & 41 \\
\hline Champasack & $\begin{array}{c}0.327 \\
(0.019)\end{array}$ & $\begin{array}{c}0.341 \\
(0.014)\end{array}$ & $\begin{array}{c}0.014 \\
{[0.024]}\end{array}$ & 0.552 & 4 \\
\hline Attapeu & $\begin{array}{c}0.331 \\
(0.062)\end{array}$ & $\begin{array}{c}0.334 \\
(0.015)\end{array}$ & $\begin{array}{c}0.003 \\
{[0.064]}\end{array}$ & 0.966 & 1 \\
\hline
\end{tabular}

LECS = Lao Expenditure and Consumption Survey.

Notes:

1. All estimates are computed using probability weights calculated by taking the inverse of the sampling fraction. Calculations are weighted by survey weights $X$ household size.

2. Linearized standard errors of point estimates in round parentheses; standard errors of changes in square parentheses. Standard errors for Gini coefficients are based on the STATA code of Jenkins (2008), which uses the method of Kovacevic and Binder (1997). Standard errors for Theil's T index are based on the STATA command of Biewen and Jenkins (2006), which uses the method of Woodruff (1971).

3. $*^{* * *},{ }^{* *}$, and ${ }^{*}$ indicate significance at $1 \%, 5 \%$, and $10 \%$ levels, respectively.

Source: Authors' calculations using LECS data from Lao Statistics Bureau.

\section{B. How Much Did Rising Inequality Affect Poverty Reduction?}

How important were the increases in inequality described above? One way of answering this question is to assess its quantitative impact on poverty reduction. This is done in the present study by decomposing observed changes in poverty incidence into two analytical components: a growth effect and an inequality effect. The growth effect is the change in poverty incidence that would, hypothetically, have occurred if all households' real expenditures had changed at the observed mean rate. That is, it is the estimated amount of poverty reduction that would have occurred if the observed aggregate rate of growth had been distributionally neutral. The inequality effect is the change in poverty incidence occurring because of the departure from distributional neutrality, calculated as the difference between the observed change in poverty incidence and the estimated growth effect. By construction, the growth effect and the distributional effect must add to the observed change. The purpose of the decomposition is analytical-to determine the relative sizes of these two effects. The question of whether changes in inequality are in fact causally related to changes in aggregate growth is not prejudged by this exercise, one way or the other.

The method is illustrated in Figure 7 and the results are summarized in Table 15. The cumulative distribution of the logarithm of nominal household expenditures is shown by the graphs "1992-1993" and "2012-2013," along with the logarithm of the official poverty lines for those years. The vertical intersection between the poverty line and the cumulative distribution gives poverty incidence for the 2 years, $46 \%$ and $23.2 \%$, respectively. The ratio of mean nominal household expenditures in 2012-2013 and 1992-1993 is 387,143/11,170 $=34.66$. The hypothetical distribution marked "2012-2013") is computed by multiplying nominal expenditure at every point on the "LECS 1" 
distribution by this number, giving the estimated distribution "2012-2013*" shown by the dashed line, that preserves the mean of "2012-2013," but which retains the same distribution as "1992-1993."16 Poverty incidence under this hypothetical distribution is then calculated using the 2012-2013 poverty line, giving $16.9 \%$. The actual change in poverty incidence was $23.2-46=-22.8 \%$. The growth effect is the difference between poverty incidence under "2012-2013" and "1992-1993" or 16.9-46 =-29.1\%. The inequality effect is the difference between poverty incidence under "2012-2013" and "2012$2013^{* \prime \prime}$ or $23.2-16.9=6.3 \%$. The growth effect was a reduction in poverty incidence of $29.1 \%(127.6 \%$ of the observed reduction) and the inequality effect was an increase of $6.3 \%$, equivalent to $27.6 \%$ of the observed decline.

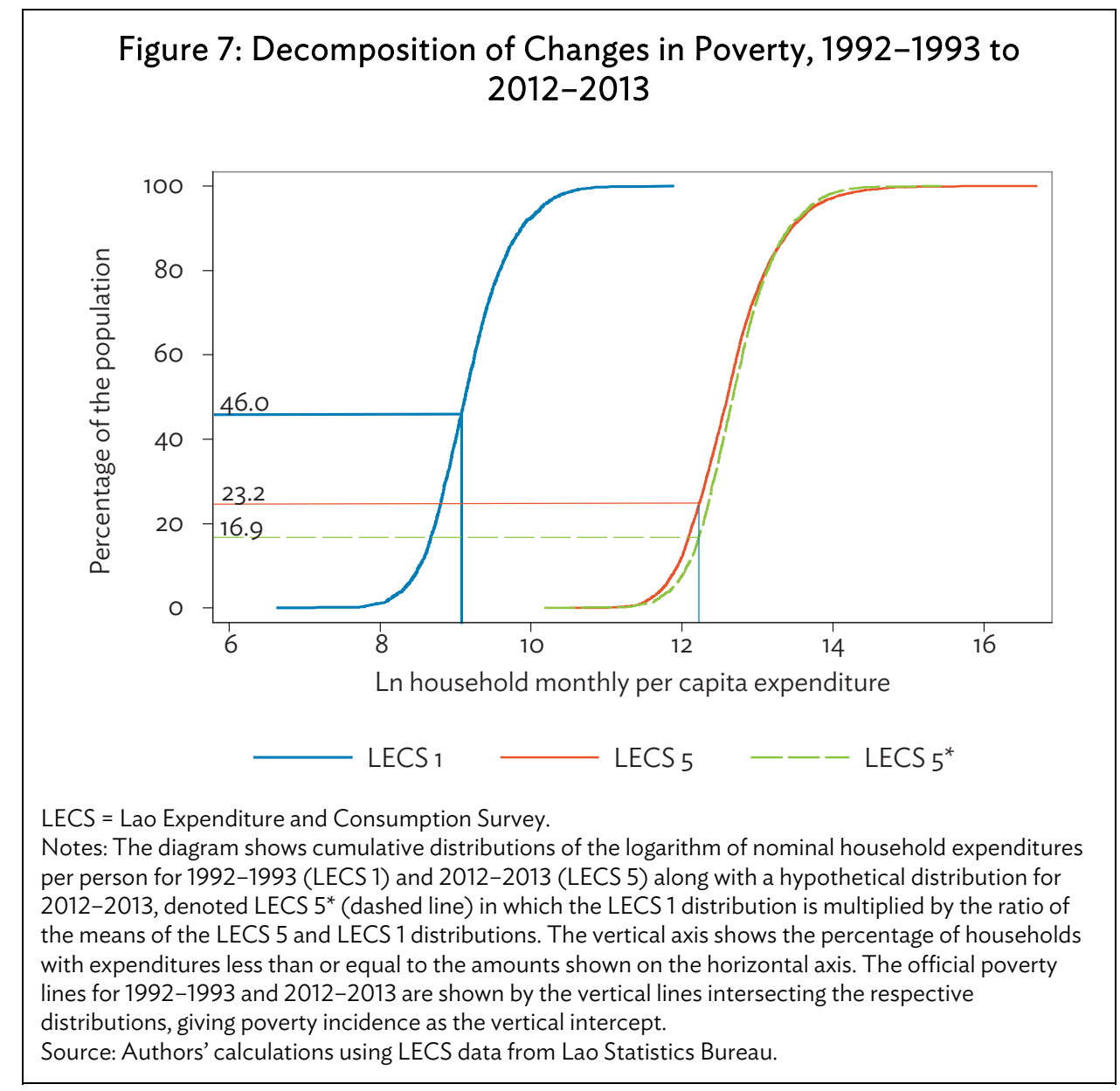

16 Since the graphs are expressed in logarithms, the computation adds the logarithm of 34.66 horizontally to each point on the "LECS 1" distribution. 
Table 15: Calculation of Growth and Inequality Effects in Poverty Reduction, 1992-1993 to 2012-2013

\begin{tabular}{lccc}
\hline & $\begin{array}{c}1992-1993 \\
\text { Observed } \\
\text { (LECS 1) }\end{array}$ & $\begin{array}{c}2012-2013 \\
\text { Observed } \\
\text { (LECS 5) }\end{array}$ & $\begin{array}{c}2012-2013 \\
\text { Hypothetical } \\
(\text { LECS 5*) }\end{array}$ \\
\hline Mean expenditures $^{\mathrm{a}}$ & 11,170 & 387,138 & 387,143 \\
Gini coefficient & 0.311 & 0.364 & 0.311 \\
Generalized entropy (1) - Theil T & 0.171 & 0.258 & 0.171 \\
Poverty incidence (\%) & $46 \%$ & $23.2 \%$ & $16.9 \%$ \\
\hline
\end{tabular}

LECS = Lao Expenditure and Consumption Survey.

a Units are kip per person per month, current prices.

Notes:

1. LECS 1 and LECS 5 describe the observed data on expenditures in 1992-1993 and 2012-2013, respectively. LECS 5* describes the hypothetical distribution in which all households expenditures rise between 1992-1993 and 2012-2013 at the observed mean rate of increase.

2. The growth effect is defined as the difference between poverty incidence under LECS $5^{*}$ and LECS $1,-29.1 \%$. The inequality effect is the difference between poverty incidence under LECS 5 and LECS $5^{*}, 6.3 \%$. By definition, the two add to the observed change in poverty incidence, the difference between poverty under LECS 5 and LECS 1, $-22.8 \%$.

Source: Authors' calculations using LECS data from Lao Statistics Bureau.

In summary, our estimates quantify the importance of the observed 2-decade increase in inequality by assessing its implications for poverty incidence. This is done by describing a hypothetical scenario in which mean expenditures increased at their observed rate, but inequality did not change. In that hypothetical case, national poverty incidence would have declined from $46 \%$ of the population to $16.9 \%$, an annual rate of decline of $1.46 \%$ of the population. This can be compared with the observed decline to $23.2 \%$ of the $2012-2013$ population, an annual rate of poverty reduction of $1.14 \%$ of the population. That is, if inequality had not changed national poverty incidence would have declined $28 \%$ more rapidly than it actually did. The implied difference in poverty incidence in 2012-2013 was 6.3\% of the population in that year (the inequality effect), or about 400,000 people out of the total population at that time of 6.5 million.

\section{INEQUALITY WITHIN AND BETWEEN GROUPS}

To what extent does nationwide inequality arise from inequality within or between provinces, rural versus urban areas or different ethnic groups? Similarly, was the increase in inequality at the national level described above mainly due to an increase within or between these categories? We now investigate these questions. The concept of inequality used in this exercise is the GE class of measures, which has the desirable feature that it can be decomposed into within group and between group components, implying that the level of inequality in a particular year can be divided into a component arising from inequality within groups and a component arising between groups. Similarly, the change in the measure for the population as a whole can be divided into a component arising from the change within groups and one from the change between groups. This decomposability property is unique to the GE class of measures, and that class does not include the Gini coefficient. Neither the level nor the change in the Gini coefficient can be decomposed into within-group and between-group components, except with a residual that lacks a simple intuitive interpretation (Aronson and Lambert 1993, Cowell 1995).

Table 16 presents a decomposition of levels of inequality for the 5 years of LECS data, decomposing total inequality into within-province and between-province components. It does this for 
three members of the $\mathrm{GE}$ class of measures, $\mathrm{GE}(\alpha)$, where $\alpha$ is a parameter determining the greater sensitivity of the measure to changes at the lower end of the distribution ( $\alpha$ below unity) at the upper end ( $\alpha$ greater than unity), or equally sensitive ( $\alpha$ equal to unity). The three most common measures correspond to $\alpha=0,1$ and 2. $\mathrm{GE}(0)$ is the Theil $\mathrm{L}$ measure, also known as the mean log deviation measure, GE(1) is Theil's T index and the GE(2) measure is also used, but less commonly.

Table 16: Decomposition of Inequality into within and between Province Components

\begin{tabular}{lccccc}
\hline $\begin{array}{l}\text { Inequality Measure } \\
\text { GE(0) }\end{array}$ & $\begin{array}{c}1992-1993 \\
\text { (LECS 1) }\end{array}$ & $\begin{array}{c}1997-1998 \\
(\text { LECS 2) }\end{array}$ & $\begin{array}{c}2002-2003 \\
(\text { LECS 3) }\end{array}$ & $\begin{array}{c}2007-2008 \\
(\text { LECS 4) }\end{array}$ & $\begin{array}{c}2012-2013 \\
\text { (LECS 5) }\end{array}$ \\
Total inequality & 0.155 & 0.240 & 0.191 & 0.224 & 0.217 \\
Within provinces & 0.120 & 0.200 & 0.160 & 0.190 & 0.180 \\
Between provinces & 0.035 & 0.040 & 0.031 & 0.034 & 0.037 \\
(\% between provinces) & $(23)$ & $(17)$ & $(16)$ & $(15)$ & $(17)$ \\
GE(1) & & & & & \\
Total inequality & 0.171 & 0.283 & 0.233 & 0.276 & 0.258 \\
Within provinces & 0.138 & 0.240 & 0.200 & 0.240 & 0.220 \\
Between provinces & 0.033 & 0.043 & 0.033 & 0.036 & 0.038 \\
(\% between provinces) & $(19)$ & $(15)$ & $(14)$ & $(13)$ & $(15)$ \\
GE(2) & & & & & \\
Total inequality & 0.237 & 0.517 & 0.386 & 0.539 & 0.515 \\
Within provinces & 0.190 & 0.470 & 0.350 & 0.500 & 0.470 \\
Between provinces & 0.037 & 0.047 & 0.036 & 0.039 & 0.045 \\
(\% between provinces) & $(16)$ & $(9)$ & $(9)$ & $(7)$ & $(9)$ \\
\hline
\end{tabular}

GE = generalized entropy, LECS = Lao Expenditure and Consumption Survey.

Source: Authors' calculations using LECS data from Lao Statistics Bureau.

The results using the three GE measures are qualitatively similar. Concentrating on the GE(1) measure, inequality within provinces is the dominant source of overall inequality, accounting for around $85 \%$ of total inequality. The proportion is slightly higher for $\alpha=0$ and slightly lower for $\alpha=2$. Turning to rural versus urban location as a grouping (Table 17), within-group inequality is even more dominant, accounting for around $88 \%$ of total inequality. Differences between provinces and between rural and urban areas contribute to total inequality, but it is variation within provinces and within rural and urban areas that accounts for most of the inequality.

Table 18 decomposes changes in inequality over time, concentrating on the GE(1) measure and focusing on the change in inequality over the full 2-decade interval between LECS 1 and LECS 5. Inequality rose both within and between provinces and the contribution of both effects to the overall increase in inequality was statistically significant. But the increase in between-province inequality explains only $6 \%$ of the overall increase. Although Table 17 shows that inequality between rural and urban areas contributes to the level of overall inequality, this statement cannot be made for the change in inequality over time. Rural/urban differences made no contribution to the observed growth of overall inequality in the Lao PDR. 
Table 17: Decomposition of Inequality into within and between Rural/Urban Components

\begin{tabular}{lccccc}
\hline $\begin{array}{l}\text { Generalized Entropy } \\
\text { Inequality Measure }\end{array}$ & $\begin{array}{c}1992-1993 \\
\text { (LECS 1) }\end{array}$ & $\begin{array}{c}1997-1998 \\
(\text { LECS 2) }\end{array}$ & $\begin{array}{c}2002-2003 \\
(\text { LECS 3) }\end{array}$ & $\begin{array}{c}2007-2008 \\
(\text { LECS 4) }\end{array}$ & $\begin{array}{r}\text { 2012-2013 } \\
(\text { LECS 5) }\end{array}$ \\
\hline GE(0) & & & & & \\
Total inequality & 0.155 & 0.238 & 0.190 & 0.217 & 0.225 \\
Within rural/urban & 0.130 & 0.210 & 0.160 & 0.190 & 0.190 \\
Between rural/urban & 0.025 & 0.028 & 0.030 & 0.027 & 0.035 \\
(\% between rural/urban) & $(16)$ & $(12)$ & $(16)$ & $(12)$ & $(16)$ \\
GE(1) & & & & & \\
Total inequality & 0.171 & 0.270 & 0.234 & 0.270 & 0.258 \\
Within rural/urban & 0.144 & 0.240 & 0.200 & 0.240 & 0.232 \\
Between rural/urban & 0.027 & 0.030 & 0.034 & 0.030 & 0.027 \\
(\% between rural/urban) & $(16)$ & $(11)$ & $(15)$ & $(11)$ & $(11)$ \\
GE(2) & & & & & \\
Total inequality & 0.230 & 0.533 & 0.388 & 0.542 & 0.520 \\
Within rural/urban & 0.200 & 0.500 & 0.350 & 0.510 & 0.480 \\
Between rural/urban & 0.030 & 0.033 & 0.038 & 0.032 & 0.040 \\
(\% between rural/urban) & $(13)$ & $(16)$ & $(10)$ & $(6)$ & $(8)$ \\
\hline
\end{tabular}

GE = generalized entropy, LECS = Lao Expenditure and Consumption Survey.

Note: $\mathrm{GE}(0), \mathrm{GE}(1)$, and $\mathrm{GE}(2)$ refer to the Generalized Entropy $\mathrm{GE}(\boldsymbol{\alpha})$ inequality measures, with $\boldsymbol{\alpha}=0,1$, and 2, respectively (Cowell 1995).

Source: Authors' calculations using LECS data from Lao Statistics Bureau.

\section{Table 18: Decomposition of Changes in Inequality within and between Provinces and Rural/Urban Areas}

\begin{tabular}{|c|c|c|c|c|c|c|}
\hline $\begin{array}{l}\mathrm{GE}(1) \text { Measure } \\
\text { of Inequality }\end{array}$ & $\begin{array}{l}1992-1993 \\
\text { (LECS 1) }\end{array}$ & $\begin{array}{c}2012-2013 \\
\text { (LECS 5) }\end{array}$ & $\begin{array}{c}\text { Difference } \\
\text { (LECS 5- } \\
\text { LECS 1) }\end{array}$ & $\begin{array}{c}p \text {-value } \\
\text { of } \\
\text { Change }\end{array}$ & $\begin{array}{l}\text { Percentage } \\
\text { Change } \\
\text { (LECS } 1 \text { to } \\
\text { LECS 5) }\end{array}$ & $\begin{array}{c}\text { Percentage } \\
\text { Change in Tota } \\
\text { Inequality } \\
\text { Due to }\end{array}$ \\
\hline \multicolumn{7}{|c|}{ Within and between provinces } \\
\hline Total inequality & $\begin{array}{c}0.171 \\
(0.010)\end{array}$ & $\begin{array}{c}0.258 \\
(0.013)\end{array}$ & $\begin{array}{l}0.0873^{* * *} \\
{[0.016]}\end{array}$ & 0.000 & 51 & 100 \\
\hline Within provinces & $\begin{array}{c}0.138 \\
(0.010)\end{array}$ & $\begin{array}{r}0.220 \\
(0.013)\end{array}$ & $\begin{array}{l}0.0821^{* * *} \\
{[0.016]}\end{array}$ & 0.000 & 60 & 94 \\
\hline Between provinces & $\begin{array}{c}0.033 \\
(0.001)\end{array}$ & $\begin{array}{c}0.038 \\
(0.002)\end{array}$ & $\begin{array}{l}0.0052^{* * *} \\
{[0.002]}\end{array}$ & 0.004 & 15 & 6 \\
\hline \multicolumn{7}{|c|}{ Within and between rural / urban areas } \\
\hline Total inequality & $\begin{array}{l}0.171 \\
(0.010)\end{array}$ & $\begin{array}{c}0.258 \\
(0.013)\end{array}$ & $\begin{array}{l}0.0873^{* * *} \\
{[0.016]}\end{array}$ & 0.000 & 51 & 100 \\
\hline Within rural/urban & $\begin{array}{l}0.144 \\
(0.009)\end{array}$ & $\begin{array}{c}0.232 \\
(0.013)\end{array}$ & $\begin{array}{l}0.0875^{* * *} \\
{[0.016]}\end{array}$ & 0.000 & 61 & 100.2 \\
\hline Between rural/urban & $\begin{array}{l}0.027 \\
(0.002)\end{array}$ & $\begin{array}{c}0.027 \\
(0.001)\end{array}$ & $\begin{array}{c}-0.0002 \\
{[0.002]}\end{array}$ & 0.941 & -1 & -0.2 \\
\hline
\end{tabular}

GE = generalized entropy, LECS = Lao Expenditure and Consumption Survey.

Notes:

1. The measure of inequality used in the table is the Theil T (GE(1)) measure.

2. All estimates are computed using probability weights calculated as the inverse of the sampling fraction. Calculations are weighted by (survey weights $X$ household size).

3. Linearized standard errors of point estimates in round parentheses; standard errors of changes in square parentheses.

4. $p$-values are calculated using the methods of Barrett and Pendakur (1995) and Davidson and Duclos (2000).

5. ***,**, and ${ }^{*}$ indicate significance at $1 \%, 5 \%$, and $10 \%$ levels, respectively.

Source: Authors' calculations using LECS data from Lao Statistics Bureau. 
Is inequality associated with ethnicity? As noted above, data on ethnicity are available only for LECS 3, LECS 4, and LECS 5. Table 9 confirms that the dominant Lao-Tai ethnic group enjoys the highest expenditure per person and also exhibits the highest within-group level of inequality in both years. Table 19 decomposes both the level and changes in the GE(1) measure into within-group and between-group components. Between-group inequality accounts for roughly $10 \%$ of the level of total inequality in each year, but accounts for none of the increase that occurred over this decade; betweengroup inequality actually declined slightly. Within-group changes account for all of the increase. The explanation for increasing overall inequality apparently does not involve ethnicity.

Table 19: Decomposition of Expenditure Inequality by Ethnicity of Household Head

\begin{tabular}{|c|c|c|c|c|c|}
\hline \multirow[b]{2}{*}{ Ethnic Group } & \multicolumn{3}{|c|}{ Generalized Entropy (1) } & \multirow[b]{2}{*}{$\begin{array}{c}p \text {-value } \\
\text { of Difference }\end{array}$} & \multirow{2}{*}{$\begin{array}{c}\text { Percent } \\
\text { Change } \\
\text { LECS } 3 \text { to } \\
\text { LECS } 5\end{array}$} \\
\hline & $\begin{array}{l}2002-2003 \\
(\text { LECS 3) }\end{array}$ & $\begin{array}{l}2012-2013 \\
\text { (LECS 5) }\end{array}$ & $\begin{array}{c}\text { Difference } \\
\text { LECS } 3 \text { to LECS } 5\end{array}$ & & \\
\hline \multicolumn{6}{|c|}{ Level of inequality } \\
\hline Lao-Tai & $\begin{array}{c}0.229 \\
(0.014)\end{array}$ & $\begin{array}{c}0.252 \\
(0.015)\end{array}$ & $\begin{array}{c}0.022 \\
{[0.020]}\end{array}$ & 0.270 & 10 \\
\hline Mon-Khmer & $\begin{array}{c}0.137 \\
(0.013)\end{array}$ & $\begin{array}{c}0.184 \\
(0.024)\end{array}$ & $\begin{array}{c}0.047 \\
{[0.027]^{*}}\end{array}$ & 0.080 & 35 \\
\hline Chinese-Tibet & $\begin{array}{c}0.114 \\
(0.018)\end{array}$ & $\begin{array}{l}0.165 \\
(0.035)\end{array}$ & $\begin{array}{c}0.051 \\
{[0.039]}\end{array}$ & 0.193 & 44 \\
\hline Mon-Mien & $\begin{array}{c}0.161 \\
(0.022)\end{array}$ & $\begin{array}{l}0.218 \\
(0.036)\end{array}$ & $\begin{array}{c}0.057 \\
{[0.043]}\end{array}$ & 0.181 & 35 \\
\hline \multicolumn{6}{|c|}{ Decomposition of level of inequality } \\
\hline $\begin{array}{l}\text { Total Inequality } \\
\%\end{array}$ & $\begin{array}{l}0.231 \\
100\end{array}$ & $\begin{array}{l}0.258 \\
100\end{array}$ & $\begin{array}{c}0.028 \\
{[0.018]}\end{array}$ & 0.124 & 12 \\
\hline $\begin{array}{l}\text { Within-group } \\
\%\end{array}$ & $\begin{array}{l}0.208 \\
90\end{array}$ & $\begin{array}{l}0.236 \\
91\end{array}$ & $\begin{array}{c}0.0276 \\
{[0.018]}\end{array}$ & 0.123 & 13 \\
\hline $\begin{array}{l}\text { Between-group } \\
\%\end{array}$ & $\begin{array}{l}0.022 \\
10\end{array}$ & $\begin{array}{l}0.022 \\
9\end{array}$ & $\begin{array}{l}-0.0004 \\
{[0.001]}\end{array}$ & 0.746 & -2 \\
\hline
\end{tabular}

Decomposition change of inequality 2002/2003 to 2012/2013

\begin{tabular}{ll}
$\begin{array}{l}\text { Total change in inequality } \\
\%\end{array}$ & 0.0275 \\
$\begin{array}{l}\text { Between-group change } \\
\%\end{array}$ & 100 \\
$\begin{array}{l}\text { Within-group change } \\
\%\end{array}$ & 0.0276 \\
\hline
\end{tabular}

LECS = Lao Expenditure and Consumption Survey.

Notes:

1. The measure of inequality used in the table is the Theil $T(G E(1))$ measure.

2. All estimates are computed using probability weights calculated as the inverse of the sampling fraction. Calculations are weighted by (survey weights $X$ household size).

3. Linearized standard errors of point estimates in round parentheses; standard errors of changes in square parentheses.

4. $p$-values are calculated using the methods of Barrett and Pendakur (1995) and Davidson and Duclos (2000).

5. ${ }^{* * *},{ }^{* *}$, and ${ }^{*}$ indicate significance at $1 \%, 5 \%$, and $10 \%$ levels, respectively.

6. All inequality estimates refer to the $\mathrm{GE}(1)$ measure, computed using probability weights calculated as the inverse of the sampling fraction.

7. Linearized Standard Errors are in round parentheses, $z$-statistics in square parentheses.

Source: Authors' calculations using LECS data from Lao Statistics Bureau. 


\section{INEQUALITY IN ACCESS TO PUBLIC SERVICES}

The discussion above has focused on inequality of privately financed consumption expenditures-the goods and services households are able to purchase with their own money. But the public sector also provides goods and services in kind, including educational and health services, and publicly provided utilities. Their value to households is not captured by data on household expenditures (or incomes). Of course, public services are not provided equally to all households. Some are able to access them more effectively than others. Standard measures of inequality therefore fail to capture the inequality that arises from this component of full household consumption. The LECS data do capture household utilization of some components of publicly provided services and utilities, especially education and health services and access to electricity networks. We now turn to these data.

Table 20 shows participation rates by expenditure quintile for primary education and lower secondary schooling, respectively. For convenience of interpretation, these data are converted, in Figures 8.a and 8.b, into the participation rates of the poorest four quintiles (Q1 to Q4) relative to the richest quintile (Q5). Richer quintiles consistently enjoy higher participation rates for both levels of education. Nevertheless, in both cases, most especially primary education, the disparity between participation rates has declined over time. This pattern corresponds to "early capture" by the richest groups, with richer groups initially able to capture a high proportion of the service provided, but with that advantage gradually eroding as the level of provision rises (Warr, Menon, and Rasphone 2014). Table 21 and Figures 8.c, 8.d, and 8.e perform a similar exercise for health care utilization rates, measured as utilization of outpatient care at hospitals and primary health centers and finally household access to the public electricity grid. ${ }^{17}$ Again, the richest quintiles initially make the most use of these facilities and the disparity between the poorest and richest quintiles has declined over time. ${ }^{18}$ In interpreting these findings, it must be stressed that the data measure the quantity of the public service delivered but not the quality. Subject to this limitation of the data, the distribution of publicly provided services has apparently become more equal over time.

Table 20: Access to Primary and Lower Secondary Schooling by Quintile Group

\begin{tabular}{lcccc}
\hline Quintile Group & $\begin{array}{c}1997-1998 \\
\text { (LECS 2) }\end{array}$ & $\begin{array}{c}2002-2003 \\
\text { (LECS 3) }\end{array}$ & $\begin{array}{c}\text { 2007-2008 } \\
\text { (LECS 4) }\end{array}$ & $\begin{array}{c}2012-2013 \\
\text { (LECS 5) }\end{array}$ \\
\hline Primary schooling (ages 6-10 years) & & & & \\
Quintile 1 (poorest) & 29.15 & 48.21 & 61.51 & 77.85 \\
Quintile 2 & 32.28 & 61.85 & 75.30 & 85.30 \\
Quintile 3 & 37.36 & 72.37 & 81.21 & 88.63 \\
Quintile 4 & 39.35 & 79.38 & 87.27 & 88.90 \\
Quintile 5 (richest) & 41.79 & 84.78 & 92.62 & 95.26 \\
All & 35.79 & 67.36 & 77.18 & 85.22 \\
Lower secondary schooling (ages 11-15 years) & & & \\
Quintile 1 (poorest) & 10.9 & 16.86 & 29.01 & 52.27 \\
Quintile 2 & 19.5 & 30.91 & 44.82 & 66.71 \\
Quintile 3 & 28.6 & 50.79 & 56.98 & 74.96 \\
Quintile 4 & 44.2 & 59.53 & 66.14 & 80.33 \\
Quintile 5 (richest) & 62.8 & 76.58 & 81.83 & 87.60 \\
All & 33.2 & 49.01 & 56.94 & 71.58 \\
\hline
\end{tabular}

LECS $=$ Lao Expenditure and Consumption Survey.

Note: These data are unavailable for 1992-1993 (LECS 1).

Source: Authors' calculations using LECS data from Lao Statistics Bureau.

17 Data on health care utilization and access to the public electricity grid, shown in Table 21 and Figures 8.c, 8.d, and 8.e, are available only for 2002-2003 (LECS 3), 2007-2008 (LECS 4) and 2012-2013 (LECS 5).

18 The exception is primary care health centers, where richer households prefer privately provided facilities. 
Table 21: Access to Health Care Facilities and Electricity by Quintile Group

\begin{tabular}{|c|c|c|c|c|c|c|c|c|c|}
\hline & \multicolumn{3}{|c|}{$\begin{array}{c}\text { Hospital-Based Outpatient Care } \\
(\%)\end{array}$} & \multicolumn{3}{|c|}{$\begin{array}{l}\text { Primary Health Center Care } \\
(\%)\end{array}$} & \multicolumn{3}{|c|}{$\begin{array}{l}\text { Electricity Supply to Home } \\
(\%)\end{array}$} \\
\hline & $\begin{array}{l}2002- \\
2003 \\
\text { (LECS 3) }\end{array}$ & $\begin{array}{c}2007- \\
2008 \\
(\text { LECS 4) }\end{array}$ & $\begin{array}{c}2012- \\
2013 \\
\text { (LECS 5) }\end{array}$ & $\begin{array}{l}2002- \\
2003 \\
\text { (LECS 3) }\end{array}$ & $\begin{array}{c}2007- \\
2008 \\
(\text { LECS 4) }\end{array}$ & $\begin{array}{c}2012- \\
2013 \\
\text { (LECS 5) }\end{array}$ & $\begin{array}{l}2002- \\
2003 \\
\text { (LECS 3) }\end{array}$ & $\begin{array}{c}2007- \\
2008 \\
\text { (LECS 4) }\end{array}$ & $\begin{array}{c}2012- \\
2013 \\
\text { (LECS 5) }\end{array}$ \\
\hline $\begin{array}{l}\text { Quintile } 1 \\
\text { (poorest) }\end{array}$ & 0.56 & 0.97 & 0.92 & 0.22 & 0.72 & 1.12 & 8.9 & 16.8 & 48.6 \\
\hline Quintile 2 & 0.87 & 0.94 & 1.12 & 0.26 & 0.50 & 0.91 & 16.8 & 35.9 & 63.6 \\
\hline Quintile 3 & 1.30 & 1.40 & 1.50 & 0.26 & 0.34 & 0.90 & 30.5 & 51.0 & 75.0 \\
\hline Quintile 4 & 1.90 & 1.80 & 1.80 & 0.50 & 0.19 & 0.77 & 49.8 & 63.7 & 80.6 \\
\hline $\begin{array}{l}\text { Quintile } 5 \\
\text { (richest) }\end{array}$ & 2.50 & 3.10 & 2.70 & 0.32 & 0.14 & 0.48 & 66.5 & 78.2 & 91.0 \\
\hline All & 1.40 & 1.60 & 1.60 & 0.31 & 0.38 & 0.85 & 33.8 & 49.2 & 70.8 \\
\hline
\end{tabular}

LECS = Lao Expenditure and Consumption Survey.

Notes: "Hospital-based outpatient care" and "primary health center care" mean the number of times the service was accessed in the previous month, divided by the population, multiplied by 100 . Because one individual may have accessed the service more than once during that month, this number may exceed the proportion of the population who accessed the service. "Electricity supply to home" means the proportion of houses connected to the electricity grid. These data are unavailable for 1992-1993 (LECS 1) and 1997-1998 (LECS 2).

Source: Authors' calculations using LECS data from Lao Statistics Bureau.

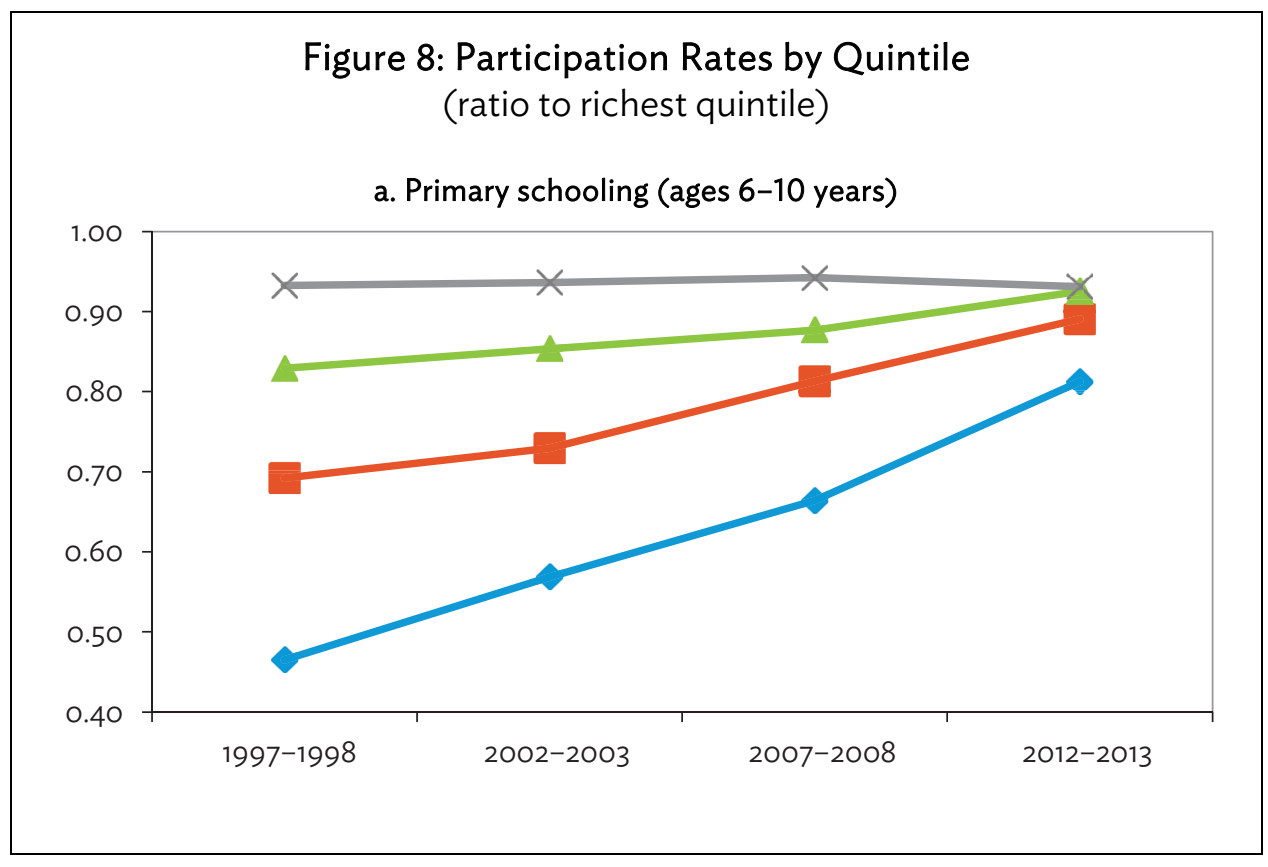

continued on next page 
Figure 8 continued

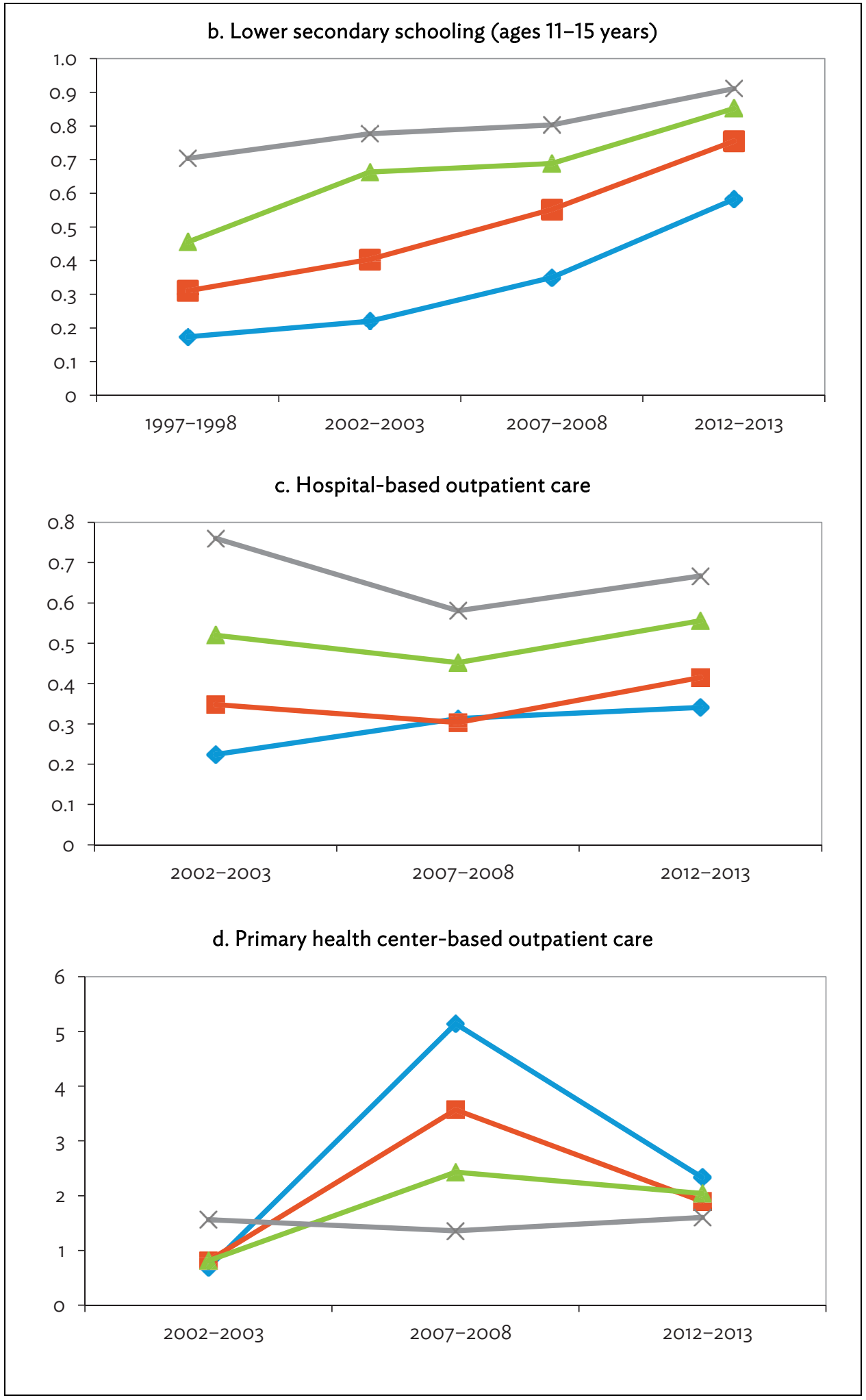

continued on next page 


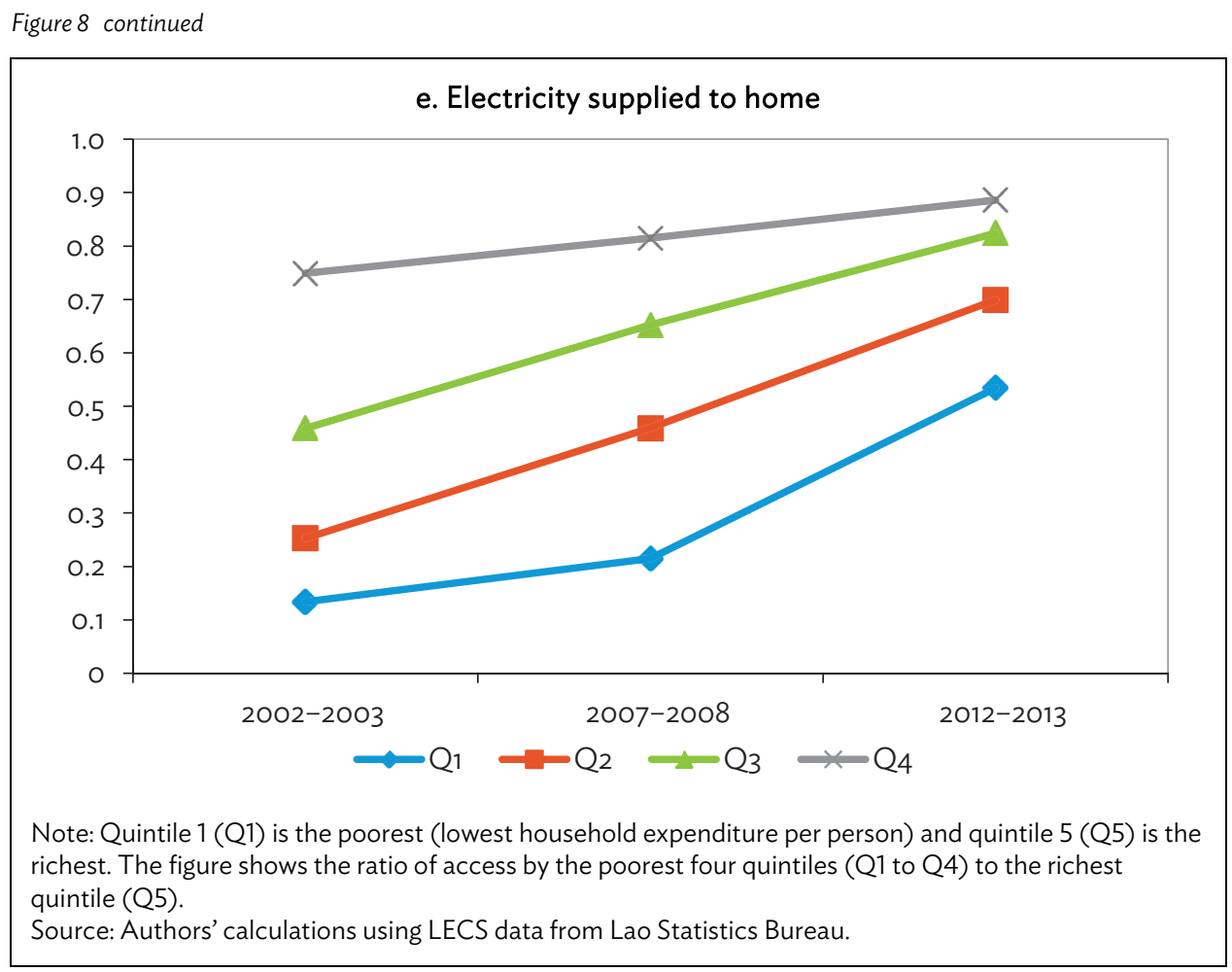

\section{CONCLUSIONS}

The available data show that over the last 2 decades the distribution of private household expenditures has become more unequal in the Lao PDR, with the Gini coefficient rising from 0.311 to 0.364, even though absolute poverty incidence has halved. The sample-based estimates on which these statements are based indicate that the measured increase in inequality is statistically significant. The analysis presented in this paper suggests that increased inequality has reduced the average rate of poverty reduction per year by about $28 \%$, meaning the actual rate compared with the counterfactual rate that would have occurred if the mean real expenditures had increased at their observed levels but inequality had not changed. When the data are decomposed into rural and urban areas of residence or by province, or by the ethnicity of the household head, the increase in inequality within groups dominates any changes between groups; inequality has increased throughout the country. In contrast, access to publicly provided services (primary education, lower secondary education, and access to health care) has become more equal; disparities in participation rates between richer and poorer groups have diminished.

Two important research questions remain unanswered by this study and may be fruitful areas for future study. First, what economic or other forces have driven the increase in private expenditure inequality demonstrated in this paper? Second, to what extent is rising inequality in the distribution of private consumption mitigated by the more equal distribution of publicly provided services? Whether the increase in expenditure inequality is already a serious public policy problem for the Lao PDR is debatable. Some increases in inequality may be inevitable in a poor country undertaking a wide-reaching program of economic reform, as in the Lao PDR over the past 2 decades. Nevertheless, if inequality continues to increase at the rate shown by this study, this issue is sure to become a focus for policy concern, even if it is not one already. 


\section{REFERENCES}

Aghion, P. and P. Bolton. 1997. A Trickle-Down Theory of Growth and Development with Debt Overhang. Review of Economic Studies. 64 (2). pp. 151-72.

Aghion, P., E. Caroli, and C. García-Peñalosa. 1999. Inequality and Economic Growth: The Perspective of the New Growth Theories. Journal of Economic Literature. 37 (4). pp. 1615-60.

Alesina, A. and R. Perotti. 1996. Income Distribution, Political Instability, and Investment. European Economic Review. 40 (6). pp. 1203-28.

Asian Development Bank (ADB). 2011. Country Partnership Strategy, Lao PDR 2012-2016. Manila.

Aronson, R. J. and P. J. Lambert. 1993. Inequality Decomposition Analysis and the Gini Coefficient Revisited. The Economic Journal. 103 (420). 1221-27.

Banerjee, A. V. and A. Newman. 1993. Occupational Choice and the Process of Development. Journal of Political Economy. 101 (2). pp. 274-98.

Barrett, G. F. and K. Pendakur. 1995. The Asymptotic Distribution of the Generalized Gini Indices of Inequality. The Canadian Journal of Economics. 28 (4b). pp. 1042-55.

Benabou, R. 1996. Inequality and Growth. NBER Working Paper No. 5658. Washington, DC: NBER.

Biewen, M. and S. P. Jenkins. 2006. Variance Estimation for Generalized Entropy and Atkinson Inequality Indices: The Complex Survey Data Case. Oxford Bulletin of Economics and Statistics. 68 (3). pp. 371-83.

Bourguinon, F. 2015. The Globalization of Inequality. Princeton: Princeton University Press.

Cambodia National Institute of Statistics. 2013. Cambodia - Cambodia Socio-Economic Survey 2012. http://www.ilo.org/surveydata/index.php/catalog/341/study-description

Chaudhuri, S. and Ravallion, M. 2006. Partially Awakened Giants: Uneven Growth in China and India. Policy Research Working Paper Series 4069. Washington, DC: World Bank.

Chong, A. and M. Gradstein. 2007. Institutional Quality and Government Efficiency. IDB Research Department Working Paper Series No. 606.

Cornia, G. 2014. Falling Inequality in Latin America: Policy Changes and Lessons. New York: Oxford University Press.

Cowell, F. A. 1995. Measuring Inequality. 2nd ed. Hemel Hempstead: Harvester Wheatsheaf.

Davidson, R. and J. Y. Duclos. 2000. Statistical Inference for Stochastic Dominance and for the Measurement of Poverty and Inequality. Econometrica. 68 (6). pp. 1435-64.

Department of Statistics, Malaysia. 2012. Household Income and Basic Amenities Survey Report 2012. http://catalog.ihsn.org/index.php/catalog/5431 
2015. Household Income and Expenditure. https://www.statistics.gov.my/index.php?r =column/cone\&menu_id=cUp6NINndGlaQkZhKOgwYUMyWFRxdz09

Dollar, D. and A. Kraay. 2002. Growth is Good for the Poor. Journal of Economic Growth. 7 (3). pp. 195225.

Elbers, C., J. O. Lanjouw, and P. Lanjouw. 2005. Imputed Welfare Estimates in Regression Analysis. Journal of Economic Geography. 5 (1). pp. 101-18.

Fosu, A. K. 2015. Growth, Inequality and Poverty in Sub-Saharan Africa: Recent Progress in a Global Context. Oxford Development Studies. 43 (1). pp. 44-59.

Galor, O. and O. Moav. 2004. From Physical to Human Capital Accumulation: Inequality and the Process of Development. Review of Economic Studies. 71 (4). pp. 1001-26.

Galor, O. and J. Zeira. 1993. Income Distribution and Macroeconomics. Review of Economic Studies. 60 (1). pp. 35-52.

General Statistics Office of Viet Nam. 2012. Poverty and Migration Profile 2012. http://www.gso.gov .vn/default_en.aspx?tabid=483\&idmid=4\&ltemID=13889

Integrated Household Living Conditions Assessment (IHLCA) Project Technical Unit, Republic of the Union of Myanmar. 2011. Integrated Household Living Conditions Assessment in Myanmar (2009-2010).

Integrated Household Living Conditions Survey in Myanmar (2009-2010) Poverty Profile. http://www .mm.undp.org/content/dam/myanmar/docs/FA1MMRPovertyProfile_Eng.pdf

Integrated Household Living Conditions Survey in Myanmar (2009-2010) Technical Report. http://www.mm.undp.org/content/dam/myanmar/docs/Publications/PovRedu/MMR_FA1_IA 2_Technical percent20Report-Eng.pdf

Jenkins, S. P. 2008. Estimation and Interpretation of Measures of Inequality, Poverty, and Social Welfare Using Stata. In North American Stata Users' Group Meetings 2006 (No. 16). Stata Users Group.

Jha, R. and A. Sharma. 2014. Poverty and Inequality: Redesigning Intervention. In A. Goyal, ed. The Oxford Handbook of the Indian Economy in the 21st Century: Understanding the Inherent Dynamism, 249-73. New Delhi: Oxford University Press.

Kaldor, N. 1957. A Model of Economic Growth. The Economic Journal. 67 (268). pp. 591-624.

Keefer, P. and S. Knack. 2002. Polarization, Politics and Property Rights: Links between Inequality and Growth. Public Choice. 111 (1). pp. 127-54.

Kovacevic, M. S. and D. A. Binder. 1997. Variance Estimation for Measures of Income Inequality and Polarization: The Estimating Equations Approach. Journal of Official Statistics. 13 (1). pp. 41-58. 
Kozel, V. 2014. Updating Vietnam's Poverty Monitoring System. In Well Begun but Not Yet Done: Progress and Emerging Challenges for Poverty Reduction in Vietnam. Washington, DC: World Bank Group. http://documents.worldbank.org/curated/en/2014/09/20204926/well-begun-not-yet -done-progress-emerging-challenges-poverty-reduction-vietnam-well-begun-not-yet-done -progress-emerging-challenges-poverty-reduction-vietnam

Kuznets, S. 1955. Economic Growth and Income Inequality. The American Economic Review. 45 (1). pp. $1-28$.

Lao Statistics Bureau. Survey Guide Book, 2002-2003, 2007-2008, and 2012-2013. Vientiane.

Liebbrandt, M., A. Finn, and I. Woolard. 2015. Describing and Decomposing Post-Apartheid Income Inequality in South Africa. Development Southern Africa. 29 (1). pp. 19-34.

Lustig, N., L. Lopez-Calva, and E. Ortiz-Juarez. 2013. Declining Inequality in Latin America in the 2000s: The Cases of Argentina, Brazil, and Mexico. World Development. 44. pp. 129-41.

Malaysia Economic Planning Unit. 2013. Household Income and Poverty. http://www.epu.gov.my/en/ household-income-poverty

Menon, J. and P. Warr. 2013. The Lao Economy: Capitalizing on Natural Resource Exports. Asian Economic Policy Review. 8 (1). pp. 70-89.

Ministry of Planning, Cambodia. Poverty Estimate in 2012 in Cambodia. http://www.mop.gov.kh/ LinkClick.aspx? fileticket $=$ McAtA9QovCA percent3D\&tabid $=148 \&$ mid $=696$

National Statistical Office, Thailand. http://web.nso.go.th/en/survey/house_seco/data/Whole percent 20Kingdom_13_FullReport.pdf

OECD. 2013. Southeast Asian Economic Outlook 2013: With Perspectives on China and India. Paris: OECD Publishing.

Philippine Statistical Agency (PSA). 2003. Notes on the Official Poverty Statistics in the Philippines. http://www.nscb.gov.ph/technotes/poverty/concept.asp

2013. Filipino Families in the Poorest Decile Earn Six Thousand Pesos Monthly, on Average in 2012 (Results from the 2012 Family Income and Expenditure Survey). http://web0.psa.gov.ph/ content/filipino-families-poorest-decile-earn-six-thousand-pesos-monthly-average-2012-results $-2012$

Phuong, N. et al. 2012. Viet Nam: Poverty Data Governance. Presentation at the Workshop on Effective Policies and Experiences for Poverty Reduction in Asia. Tokyo. 23-25 October.

Pinkovskiy, M. L. and X. Sala-i-Martin. 2014. Africa Is on Time. FRB of New York Staff Report No. 686. 1 August.

Priebe, J. 2014. Official Poverty Measurement in Indonesia Since 1984: A Methodological Review. Bulletin of Indonesian Economic Studies. 50 (2). pp. 185-205. http://www.tandfonline.com/doi/ pdf/10.1080/00074918. 2014.938406 
Ravallion, M. 2007. Inequality is Bad for the Poor. Chapter 2. In S. Jenkins and J. Micklewright, eds. Inequality and Poverty Re-examined. Oxford: Oxford University Press.

Sicular, T. 2013. The Challenge of High Inequality in China. Inequality in Focus. 2(2) August 2013. Washington, DC: World Bank.

Sonin, K. 2003. Why the Rich May Favor Poor Protection of Property Rights. Journal of Comparative Economics. 31 (4). pp. 715-31.

Soukhathammavong, N., O. Duanmany, and V. Sisoulath. 2012. Policies and Practices on Poverty Eradication in Lao PDR. Presentation at the Workshop on Effective Policies and Experiences for Poverty Reduction in Asia. 23-25 October 2012. http://www.adbi.org/files/2013.05.08 .cpp.sess3.1.poverty.eradication.lao.pdr.pdf

Statistical Yearbook Thailand. 2013. http://web.nso.go.th/en/pub/e_book/YEARBOOK_2013/

Statistics Indonesia. 2014a. Computation and Analysis of Macro Poverty of Indonesia 2014. http://www.bps.go.id/index.php/publikasi/919

_. 2014b.Welfare Indicators 2014. http://www.bps.go.id/index.php/publikasi/883

United Nations Development Programme (UNDP). 2007. Assessment of Development Results. Evaluation of UNDP's Contribution-Lao PDR.

_. 2011. Integrated Household living Conditions Survey in Myanmar (2009-2010): Poverty Profile. Yangon, Myanmar.

Warr, P., J. Menon, and S. Rasphone. 2014. Public Services and the Poor in Laos. World Development. 66. pp. 371-82.

Woodruff, R. S. 1971. A Simple Method for Approximating the Variance of a Complicated Estimate. Journal of the American Statistical Association. 66 (334). pp. 411-14.

World Bank. 2010. Lao PDR Development Report 2010: Natural Resource Management for Sustainable Development - Hydropower and Mining. Washington, DC: World Bank.

2012. Lao People's Democratic Republic - Country Partnership Strategy for the Period FY12FY16. Washington, DC: World Bank.

2014. Myanmar: Ending Poverty and Boosting Shared Prosperity in a Time of Transition. A Systematic Country Diagnostic. Washington, DC: World Bank.

W. World Development Indicators. http://data.worldbank.org/data-catalog/world-developmentindicators

Zhuang, J. 2010. Poverty, Inequality and Inclusive Growth: Measurement, Policy Issues, and Country Studies. Anthem Press / ADB. 


\section{Two Decades of Rising Inequality and Declining Poverty in the Lao People's Democratic Republic}

Over the last 2 decades the Gini coefficient for expenditure in the Lao People's Democratic Republic has risen from 0.311 to 0.364 , even though absolute poverty incidence has halved. When the data is decomposed into rural and urban areas, or by the ethnicity of the household head, the increase in inequality within groups dominates any changes between groups; indeed, inequality has increased throughout the country. In contrast, access to publicly provided services has become more equal.

\section{About the Asian Development Bank}

ADB's vision is an Asia and Pacific region free of poverty. Its mission is to help its developing member countries reduce poverty and improve the quality of life of their people. Despite the region's many successes, it remains home to the majority of the world's poor. $A D B$ is committed to reducing poverty through inclusive economic growth, environmentally sustainable growth, and regional integration.

Based in Manila, ADB is owned by 67 members, including 48 from the region. Its main instruments for helping its developing member countries are policy dialogue, loans, equity investments, guarantees, grants, and technical assistance. 